\title{
Origin and evolution of the Kangâmiut mafic dyke swarm, West Greenland
}

\author{
Kyle R. Mayborn and Charles E. Lesher
}

The Kangâmiut dyke swarm in West G reenland intruded Archaean terrains at $2.04 \mathrm{Ga}$, and its northern portion was subsequently metamorphosed to granulitefacies during the $N$ agssugtogidian orogeny (c. $1.8 \mathrm{G}$ a). Mineral and wholerock major and trace element compositions show that the parental magmas for the dyke swarm differentiated by the fractionation of olivine, clinopyroxene, plagioclase and latestage $\mathrm{Fe}-\mathrm{T} i$ oxides. Petrographical observations and the enrichment of $\mathrm{K}_{2} \mathrm{O}$ during differentiation argue that hornblende was not an important fractionating phase. Field observations suggest emplacement at crustal levels above the brittle-ductile transition, and clinopyroxene geothermobarometry constrains dyke emplacement depths to less than $10 \mathrm{~km}$. Granulite facies metamorphism of the Kangâmiut dykes and their host rocks in the northern portion of the swarm requires subsequent burial to c. $30 \mathrm{~km}$, related to roughly $20 \mathrm{~km}$ of crustal thickening between the time of dyke emplacement and peak metamorphism during the $\mathrm{N}$ agssugtogidian orogeny. Kangâmiut dykes are characterised by low $\mathrm{Ba} / \mathrm{La}$ ratios $(12 \pm 5)$, and high $\mathrm{N}$ b/La ratios $(0.8 \pm 0.2)$, compared to subduction related basalts (Ba/La c. 25; N b/La c. 0.35). These geochemical characteristics argue that the Kangâmiut dykes are not related to subduction processes. Forward modelling of rare-earth element data requires that primitive magmas for the Kangâmiut dykes originated from a moderately depleted mantle source with a mantle potential temperature of $\mathrm{c} .1420^{\circ} \mathrm{C}$. The inferred potential temperature is consistent with potential temperature estimates for ambient mantle at $2.0 \mathrm{G}$ a derived from secular cooling models and continental freeboard constraints. The geochemistry and petrology of the Kangâmiut dykes support a model that relates the dyke activity to passive rifting of the proposed Kenorland supercontinent rather than to mantle plume activity or subduction.

Keywords: dyke swarm, Laurentia, Palaeoproterozoic, rifting

K.R.M., D epartment of G eology, Western Illinois U niversity, M acomb, IL 61455, U SA. E-mail: KR-M ayborn@wiu.edu C.E.L., D epartment of Geology, University of California-D avis, Davis, CA 95616, USA.

The 2.04 Ga Kangâmiut dyke swarm of W est Greenland has been the subject of numerous investigations over the past 35 years (W indley 1970; Escher et al. 1976; Bridgwater et al. 1995; Cadman et al. 1999), yet there is still considerable disagreement over many aspects of the swarm's history. Since the work of Escher et al. (1976), who associated the dykes with synkinematic shearing during $\mathrm{N}-\mathrm{S}$ compression, the swarm has often been cited as a type example of dykes that are emplaced into crustal regions undergoing shear deformation (C adman et al. 1999). The proposed compressional setting led Cadman et al. (2001) to speculate that the swarm formed in a subduction-related environment. $\mathrm{N}$ evertheless, recent geochronology has shown that many of the shear zones originally thought to be consanguineous with the dykes are actually significantly older or younger than the dykes themselves (Connelly \& M engel 2000). The field area for Escher et al.'s (1976) investigations is now known to contain Archaean shear 
zones and post-K angâmiut dyke shearing associated with the N agssugtogidian orogeny. D espitethese complications, the Kangâmiut dyke swarm offers a unique opportunity to constrain the magmatic and tectonic evolution of the province spanning the period from dyke emplacement to the Nagssugtogidian orogeny $(2.04$ to $c .1 .8 \mathrm{Ga})$. The present work discusses the constraints on the magmatic and metamorphichistory of theK angâmiut dykesprovided by field observations, petrology, geochemistry, and geochronology and critically evaluatespreviousand newly proposed models for their origin and subsequent metamorphism during the $\mathrm{N}$ agssugtogidian orogeny.

\section{Regional geology}

Figure 1 is a geological map of central West Greenland showing the N agssugtogidian orogen and the Kangâmiut dykes. The Nagssugtogidian orogen is bounded to the north by the Palaeoproterozoic Rinkian orogen (Escher $\&$ Pulvertaft 1976) and to the south by the Archaean N ain craton (N utman \& Bridgwater 1986; N utman \& Collerson 1991; Friend \& N utman 1994). T he orogen is divided into four parts based on lithology, structure, stream sediment geochemistry, and aeromagnetic data. From north to south, these are the northern Nagssugtogidian orogen ( $\mathrm{N} \mathrm{NO}$ ), the central $\mathrm{N}$ agssugtogidian orogen (CN O), the southern N agssugtogidian orogen (SN O ), and the southern $N$ agssugtogidian foreland (SN F). These terrains are separated by threeshear zones. TheN ordreStrømfjord shear zone separates the N N $O$ from the $\mathrm{CN} O$, the I kertôq shear zone separates the CNO from the SN O, and theN agssugtogidian Front separatestheSN $O$ from the SN F.

The N N O contains Archaean granitic gneisses and supracrustal rocks (van Gool et al. 2002), whereas the CN $O$ is characterised by reworked Archaean granitic and tonalitic gneisses, the $1.92 \mathrm{G}$ a Arfersiorfik quartz diorite, the $1.92 \mathrm{G}$ a Sisimiut charnockite, and supracrustal rocks (Bak et al. 1975; Kalsbeek et al. 1987; M anatschal et al. 1998; K alsbeek \& M anatschal 1999; N utman et al. 1999; van $G$ ool et al. 1999). The SN $O$ and SN F are composed of Archaean granitic and tonalitic gneisses and the Kangâmiut dykes. In the SN 0 the dykes are metamorphosed to amphibolite facies in the south and granulite facies in the extreme north. The transition from amphibolite facies to granulite facies occurs within the I kertôq shear zone (Korstgård 1979). In the SN F, most of the Kangâmiutdykesretain igneoustexturesand mineralogies.

Figure 1 shows that the l kertôq shear zone is the most continuousstructure within the N agssugtogidian orogenic belt and represents an important lithological boundary between the SN 0 and the C N O. It is traceable from the western shoreline, just south of the village of Sisimiut, to the inland icecap. The shear zone contains panels of Kangâmiut dyke-bearing tonalitic gneiss alternating with layers of garnet-sillimanite-kyanite-bearing metapelites, marbles, and quartzites that dip steeply N N W. The repetition of lithological units, the presence of down-dip lineations and S-vergent kinematic indicators show that this structure is a reverse fault ( $G$ rocott 1979). D eformed Kangâmiut dykes are restricted to the southern footwall, whilePalaeoproterozoic fel sic igneous rocks, including the $1.92 \mathrm{G}$ a Sisimiut charnockite and the $1.92 \mathrm{Ga}$ Arfersiorfik quartz diorite, are found only north of the shear zone. $\mathrm{U} / \mathrm{Pb}$ datesfor detrital zirconsfrom the supracrustal rocks of the region require that these units were deposited after $2.10 \mathrm{Ga}$ (N utman et al. 1999), while ${ }^{40} \mathrm{Ar} /{ }^{39} \mathrm{Ar}$ dating of hornblende from metamorphosed Kangâmiut dykes and orthogneisses from within the shear zone gives cooling ages of c. $1.73 \mathrm{Ga}$ (W illigers et al. 1999).

The Itivdleq shear zone is located to the south of the I kertôq shear zone within the SN 0 and is c. $6 \mathrm{~km}$ wide with $\mathrm{E}-\mathrm{W}$-trending lineations ( $\mathrm{H}$ anmer et al. 1997). It contains multiple bands of sheared $K$ angâmiut dykes and Archaean orthogneisses that C onnelly \& M engel (2000) used to document shearing during the Archaean and the Palaeoproterozoic N agssugtogidian orogeny. For example, some of the shear bands are cut by weakly deformed tonalites that yield a magmatic age of $2498 \pm 4 \mathrm{M}$ a with a metamorphic overprint at $1782 \pm 12 \mathrm{Ma}$ (Connelly \& $M$ engel 2000). This shows that some of the shear bands near Itilleq fjord developed prior to c. $2.5 \mathrm{Ga}$ and were subsequently intruded by tonalite. T hemetamorphic overprint age of $1782 \mathrm{M} \mathrm{a}$ and the presence of shear bands that cut the Kangâmiut dykes indicate reactivation during the $\mathrm{N}$ agssugtoqidian orogeny. M etamorphic hornblende from a recrystallised Kangâmiut dyke within the Itivdleq shear zone gives an ${ }^{40} \mathrm{Ar} /{ }^{39} \mathrm{Ar}$ age of $1873 \pm 13$ $\mathrm{M} \mathrm{a}$, consistent with the age of $\mathrm{N}$ agssugtogidian metamorphism (W illigers et al. 1999).

The $N$ agssugtogidian Front is the southernmost structural expression of the $\mathrm{N}$ agssugtogidian orogenic event (Fig. 1). H ageskov (1995) showed that it is a discontinuous, en échelon array of N W-dipping, low-angle thrust

\section{Facing page:}

Fig. 1. Geological map of the Nagssugtogidian orogen and its southern foreland in West G reenland. $\mathbf{N} \mathbf{N} \mathbf{0}$, northern Nagssugtogidian orogen; C N $\mathbf{O}$, central N agssugtogidian orogen; $\mathbf{S N} \mathbf{0}$, southern N ags sugtogidian orogen; SN F, southern N agssugtogidian foreland. M odified from van Gool et al. (2002). 


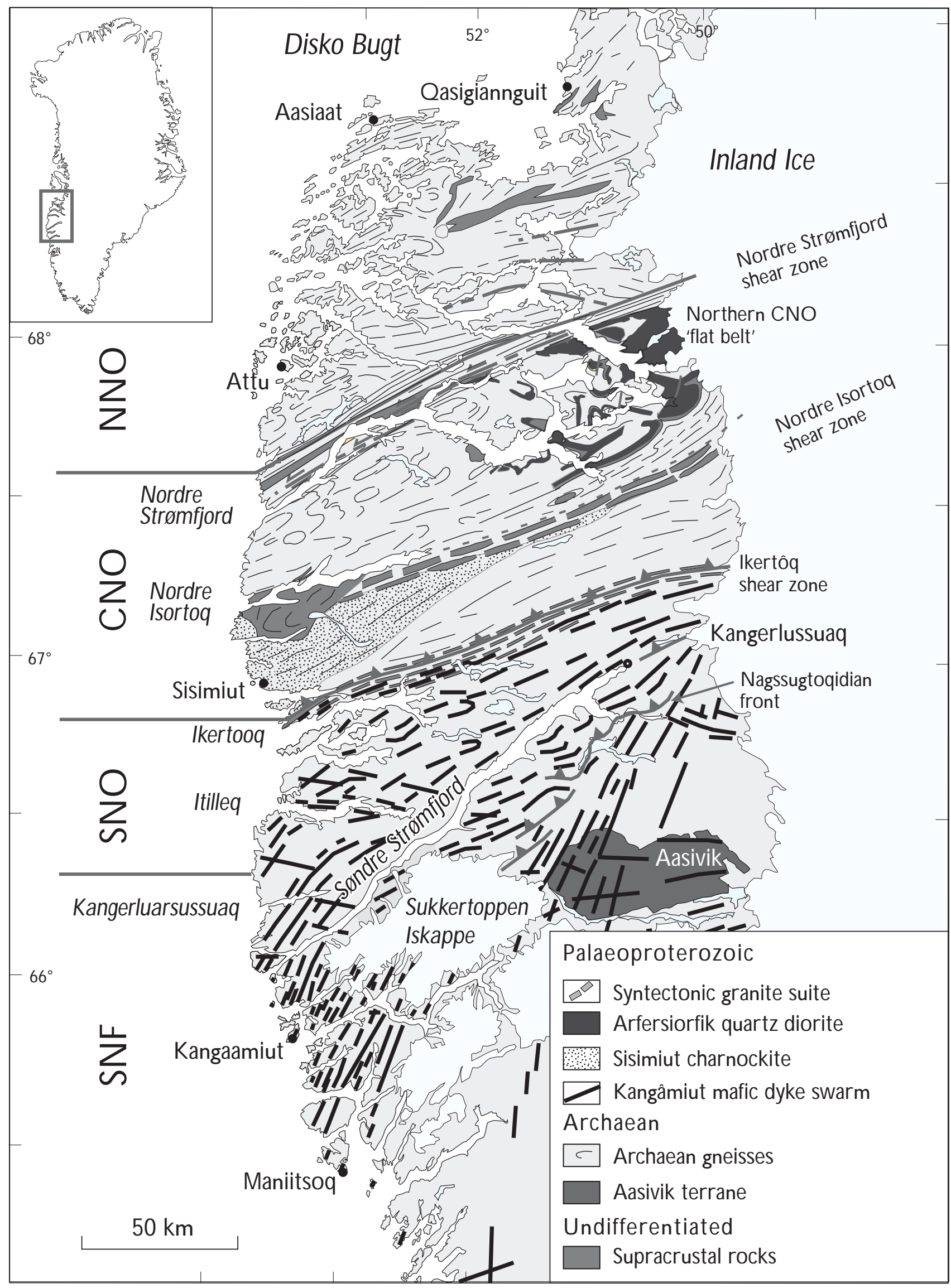


faults that deformed the Kangâmiut dykes in this region. The N agssugtogidian Front is well defined in the eastern portion of the orogen but is difficult to trace to the west approaching the Sukkertoppen I skappe. It is not known whether the N agssugtogidian Front dies out beneath the icecap or swings to the N N W merging with the Itivdleq shear zone (H ageskov 1995).

\section{Geological history}

ThePrecambrian history of central W est $G$ reenland involves fivemajor events: (1) genesisand metamorphism of Archaean crust; (2) emplacement of the K angâmiut dykes (2.04 $\mathrm{Ga}$ ); (3) deposition of sediments (c. 2.00-1.92 Ga); (4) emplacement of the Sisimiut and Arfersiorfik intrusions (c. 1.92-1.87 G a); and (5) metamorphism and deformation accompanying the $\mathrm{N}$ agssugtogidian orogeny (c. 1.82$1.77 \mathrm{Ga})$.

\section{Genesis and metamorphism of A rchaean crust}

Connelly \& M engel (2000) and Kalsbeek \& Nutman (1996) present U/Pb dates and field observations that document the genesis and metamorphism of a large portion of the central West Greenland crust during the Late Archaean. I gneous zircons from foliated granulite facies gneisses give ages between 2.87 and $2.81 \mathrm{Ga}$. G ranitoids that cut the foliation in these gneisses give ages between 2.81 and $2.72 \mathrm{Ga}$. These cross-cutting relationships and dates indicate widespread genesis of granitic crust between 2.87 and $2.81 \mathrm{Ga}$, immediately followed by metamorphism at 2.81-2.72 $\mathrm{Ga}$.

\section{Emplacement of the Kangâmiut dykes}

The emplacement of the Kangâmiut dykes occurred after the formation of the Archaean host rocks and before the $\mathrm{N}$ agssugtogidian orogeny. U/Pb geochronology on igneous zircons from three dykes gives ages of $2036 \pm 5 \mathrm{M} \mathrm{a}$, $2046 \pm 8 \mathrm{Ma}$ (N utman et al. 1999), and $2048 \pm 4 \mathrm{Ma}$ (Connelly et al. 2000). The analysed zircons come from dioritic centres in wide composite dykes and cover most of the $\mathrm{N}-\mathrm{S}$ extent of the dyke swarm. ${ }^{40} \mathrm{Ar} /{ }^{39} \mathrm{Ar}$ dating of hornblende from the Kangâmiut dykes from the SN F by Willigers et al. (1999) gives emplacement related ages of 2.05-2.02 Ga.

\section{Deposition of sediments}

$D$ ating of detrital zirconsfrom metasedimentary units just south of the N ordre Strømfjord shear zone and within the Ikertôq shear zone (Fig. 1) yields ages between 3.4 and $1.95 \mathrm{G}$ a (N utman et al. 1999). Some metasediments containing $1.95 \mathrm{G}$ a zircons are cut by $1.92 \mathrm{Ga}$ quartzdiorites, requiring that deposition of the sediments occurred between 1.95 and $1.92 \mathrm{Ga}$. M etasediments found within thrust-bounded panels in the I kertôq shear zone contain zircons that yield ages between 2.1 and $2.0 \mathrm{Ga}$. There are no known granitic intrusive rocks with ages between 2.5 and $1.92 \mathrm{G}$ a within the central West Greenland field area, suggesting that the sediments originated from a distal source. N utman et al. (1999) propose that the Archaean and Palaeoproterozoic terranes of eastern Canada are possible source regions. Sediments derived from these terranes would support the existence of the supercontinent Kenorland (Williams et al. 1991; Aspler \& C hiarenzelli 1998). Additionally, the deposition of sediments suggests the presence of basins that may have developed during the rifting and break-up of Kenorland (van Gool et al. 2002).

The $\mathrm{N}$ agssugtogidian orogeny and emplacement of Sisimiut and Arfersiorfik intrusions

Ramberg (1949) and N oe-N ygaard (1952) first recognised the $N$ agssugtogidian orogen based on the deformation and metamorphism of the Kangâmiut dykes and the occurrence of shear zones with steeply dipping foliations. G eochronological datashow that theN agssugtogidian orogenic event occurred between 1.91 and $1.77 \mathrm{Ga}$ (Connelly et al. 2000) and resulted in granulite to amphibolite grade metamorphism and the development of discrete shear zones. Pre-orogenic magmatism includes the emplacement of the $1.92 \mathrm{G}$ a Arfersiorfik quartz diorite (K alsbeek et al. 1987) and the $1.92 \mathrm{Ga}$ Sisimiut charnockite. The orogenic event is proposed to be the result of continental collision that produced thrust stacking, folding and associated metamorphism (van Gool et al. 2002). The suture between the two continents is not easily identifiable, but Kalsbeek et al. (1987) proposed that the suture is located in what is now the boundary between the $\mathrm{N} \mathrm{NO}$ and the CNO. 


\section{Previous work on the origin of the Kangâmiut dykes}

$M$ any early workerssuggested that theemplacement of the Kangâmiut dykes was directly related to the Nagssugtoqidian orogeny. Escher et al. (1976) stated that the dykes were emplaced into conjugate sets of active shear zones duringN N W -SSE compression. They based thishypothesis on their observations of conjugate sets of dykes that show a variety of cross-cutting relationships. They, and $\mathrm{H}$ anmer et al. (1997), proposed that the emplacement of both dyke sets occurred during shearing. Bridgwater et al. (1995) expanded on the Escher et al. (1976) hypothesis by proposing that the dykes formed during thrusting of amphibolite facies crust from the north under the granulite facies terrain in the southern Nagssugtogidian orogen. They invoked this hypothesis becausethe K angâmiut dykes contain hornblendesuggesting they crystallised from a hydrous magma. Bridgwater et al.'s (1995) hypothesis seeks to explain thehydrous nature of theK angâmiut dyke magmas by placing a hydrous source beneath the granulitefacies host rocks. A potential problem with the Escher et al. (1976) and Bridgwater et al. (1995) hypotheses is that neither easily explains how partial melting of hydrous lower crust would directly produce melt of basaltic composition. If the Escher et al. (1976) and Bridgwater et al. (1995) hypotheses of dyke emplacement during compression are correct, then subduction related magmatism becomes a possibility. Cadman et al. (2001) explicitly consider this possibility and proposed that the Kangâmiut dyke swarm formed by adiabatic decompression of metasomatised mantle during passage of a slab window.

The recent work of Kalsbeek \& M anatschal (1999), Connelly \& Mengel (2000) and van Gool et al. (2002), offer alternatives to the subduction hypothesis and suggest that theswarm wasemplaced during continental rifting. Van Gool et al. (2002) cite evidence of $2.0 \mathrm{Ga}$ rift related sediments in support for the rifting hypothesis. Kalsbeek \& M anatschal (1999) speculate that the Kangâmiut dykes are the product of mantle plume-related rifting based on the presence of ultramafic rocks found within the N agssugtogidian orogeny. Although these authors discuss the origin of the Kangâmiut dykes, they do so only briefly, because their primary focusis on the $\mathrm{N}$ agssugtoqidian orogeny.

\section{Field setting}

The Kangâmiut dyke swarm intruded granulite facies Archaean orthogneisses and is exposed over an $18000 \mathrm{~km}^{2}$ area. Figure 1 shows that the swarm extends for $150 \mathrm{~km}$ from just south of the village of $\mathrm{M}$ aniitsoq towards Sisimiut in the north and from the coast eastward to the ice cap. The dykes are most abundant near the coast and less so towards the ice cap. D yke widths range from a few centimetres to greater than $140 \mathrm{~m}$. Escher et al. (1975) estimated that dyke emplacement was accommodated by 2-3\% crustal extension. Appendix A provides locality and field characteristics of all the dykes examined in this study.

Field observations show that there are three dyke suites (M engel et al. 1996). Two of these trend east-west, while the third has a N E trend. T he N E-trending suite of dykes represents the vast majority of the dykes in the area and is the only suite that contains dykes with dioritic centres. The three sets of zircon populations used to date three separate dykes all come from these dioritic centres ( $N$ utman et al. 1999; Connelly et al. 2000). Thus, the NEtrending suite is dated at $2.04 \mathrm{Ga}$ and will be referred to as the 'K angâmiut dykes' proper as suggested by $M$ engel et al. (1996).

Although the Kangâmiut dykes have an overall NE trend, there are some systematic deviations. Figure 1 shows that the southern portion of the swarm trends N NE. $M$ oving northward, the orientation gradually changes to ENE. Changes in the orientation of the swarm correlate with increased dyke deformation and recrystallisation. Escher et al. (1975) suggested that the bend in the swarm resulted from deformation during the Nagssugtogidian. $\mathrm{H}$ anmer et al. (1997) argue that this change in orientation is a primary feature related to the regional stress field during dyke emplacement.

The majority of dykes south of the $\mathrm{N}$ agssugtogidian Front retain igneous mineralogies and textures with the exception of a small number of composite dykes with sheared dioritic centres. Shearing was parallel to the dyke contacts, and mostly affected the large composite dykes. W indley (1970) worked in an area just north of M aniitsoq village where he observed cross-cutting dykes. He described a set of cross-cutting dykes where a younger dyke cuts the internal foliation of an older dyke. $\mathrm{N}$ ot all of the composite dykes show internal deformation. Some dykes show irregular intrusive contacts between the dioritic centre and mafic host dyke showing that they formed by successive injections, closely spaced in time.

Large composite dykes show structural and petrological features not seen in the smaller non-composite dykes. For example, a $140 \mathrm{~m}$ wide dyke in Kangerluarsussuaq fjord has fine-grained (c. 0.1-0.5 mm) equigranular mafic contacts. Twelve metres from the contact the grain size is c. $1 \mathrm{~mm}$ with some contact-parallel primary layering. $\mathrm{H}$ alfway towards the dyke centre the grain size increases 


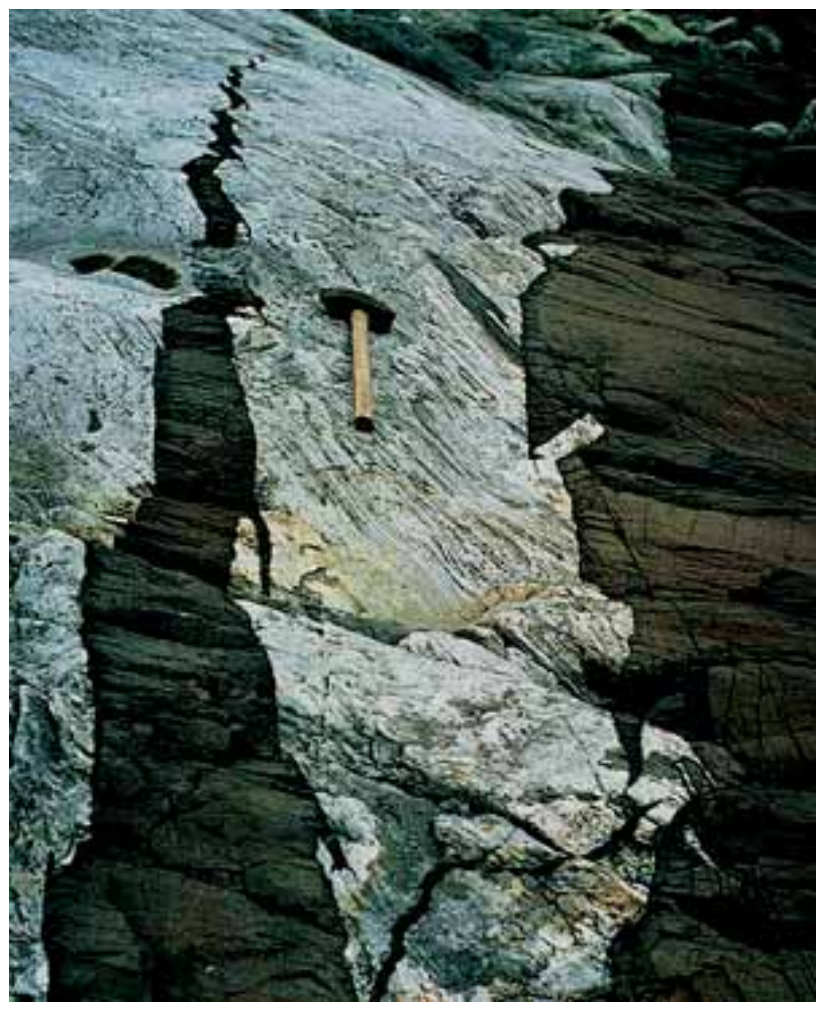

Fig. 2. Kangâmiut dyke with angular bridges within the chilled margin (Photo: D avid Bridgwater).

to c. $3 \mathrm{~mm}$ with primary clinopyroxene mostly replaced by hornblende. $\mathrm{N}$ ear its centrethe dykeis slightly foliated and recrystallised to a garnet amphibolite. The centre of the dyke is a strongly foliated garnet-plagioclase-hornblende schist with a dioritic composition. A $10 \mathrm{~cm}$ wide epidote-calcite-quartz vein originates from the sheared centre and cutsthe non-sheared mafic portion of the dyke.

There are a variety of intrusive relationships between dykes and host rocks including en échelon steps, bridges, and forks. Figure 2 shows bridges with sharp, angular edges contained within the chilled margin of a K angâmiut dyke. Some dykes have chilled margins up to $40 \mathrm{~cm}$ thick, while others have no chilled margins. Chilled margins contain fine-grained plagioclase and clinopyroxenephenocrysts in a microcrystallinegroundmass. Somechilled margins contain dismembered bridges of host rock, whereas dyke interiors contain no bridges or xenoliths.

In the northern portion of the dyke swarm, metamorphic minerals and deformation features replace igneous minerals and primary intrusivefeatures. In theltilleq fjord region, most of the dykes are partly to completely altered during static or shear-related recrystallisation. Some dykes show penetrative foliation, whereas other dykes are deformed only at the contacts and form boudins within the deformed country rock. Thecentral portions of theseboudins are partially recrystallised. On the south shore of I tillea fjord, away from most of the $\mathrm{N}$ agssugtogidian deformation, the dykes preserve primary emplacement structures, but are statically recrystallised to garnet amphibolites. Dykes at the northern extent of the swarm within Ikertooq fjord are completely recrystallised to granulitefacies.

\section{Petrography}

The chilled margins of the Kangâmiut dykes contain 0.2$0.8 \mathrm{~mm}$ phenocrysts of clinopyroxene and plagioclase in a microcrystalline groundmass of plagioclase, clinopyroxene, hornblende, quartz, and Fe-Ti oxides. Plagioclase phenocrysts are euhedral to subhedral and weakly zoned, whereas the clinopyroxene phenocrysts are subhedral to anhedral. Somechilled margins contain 0.2-1.5 mm hornblende crystals. Figure $3 \mathrm{~A}$ shows that these hornblende crystals contain abundant inclusions of Fe-Ti oxides, which are absent from the clinopyroxene and plagioclase phenocrysts. These hornblende crystals al so enclose plagioclase and clinopyroxene phenocrysts suggesting they are a later phase that crystallised in situ.

The interiors of most Kangâmiut dykes are fine- to medium-grained with subophitic textures. Subhedral to anhedral clinopyroxene, plagioclase, and Fe-Ti oxides are the primary constituents along with interstitial quartz, hornblende, and trace amounts of apatite. In some of the dykes, anhedral clinopyroxenefillsinterstitial areas between subhedral to euhedral plagioclase. Clinopyroxene displays two types of exsolution. The first type is laminar exsolution of low-C a pyroxene. The second type appears to be granular exsolution of low-C a pyroxene around the outer parts of the original clinopyroxene crystal. Additionally, most clinopyroxene grains have rims of hornblende (Fig. 3B).

Kangâmiut dyke samples from Itilleq fjord are variably metamorphosed to fine-grained $(0.2-1.0 \mathrm{~mm})$ amphibolites with well-developed foliations. M etamorphic assemblages include hornblende, plagioclase, quartz, garnet, titanite, and biotite. $\mathrm{H}$ ornblende replaces clinopyroxene, whereas plagioclase and garnet form at contacts between hornblende and plagioclase (see al so M engel et al. 1996). Titanite replaces $\mathrm{Fe}-\mathrm{Ti}$ oxides.

M etamorphic orthopyroxene occurs within Kangâmiut dykes in Ikertooq fjord near the northern extent of the swarm (Fig. 1), marking the transition from amphibolite to granulite facies. The typical assemblage in these granulite facies dykes is plagioclase + hornblende +orthopyroxene +clinopyroxene \pm garnet \pm titanite (seeal so Korstgård 
Fig. 3. A: P hotomicrograph of a chilled margin of a Kangâmiut dyke with clinopyroxene (C PX) and plagioclase (PLAG) phenocrysts in a groundmass of the same plus Fe-Ti oxides. The large crystal in the centre is hornblende (H BL) with inclusions of a plagioclase phenocryst and groundmass plagioclase and Fe-Ti oxides. Sample G GU 430267, plane polarised light. B: Photomicrograph of a sample from the interior of a Kangâmiut dyke showing hornblende ( $\mathrm{HBL}$ ) rims on clinopyroxene (CPX). Sample G GU 430999, plane polarised light.
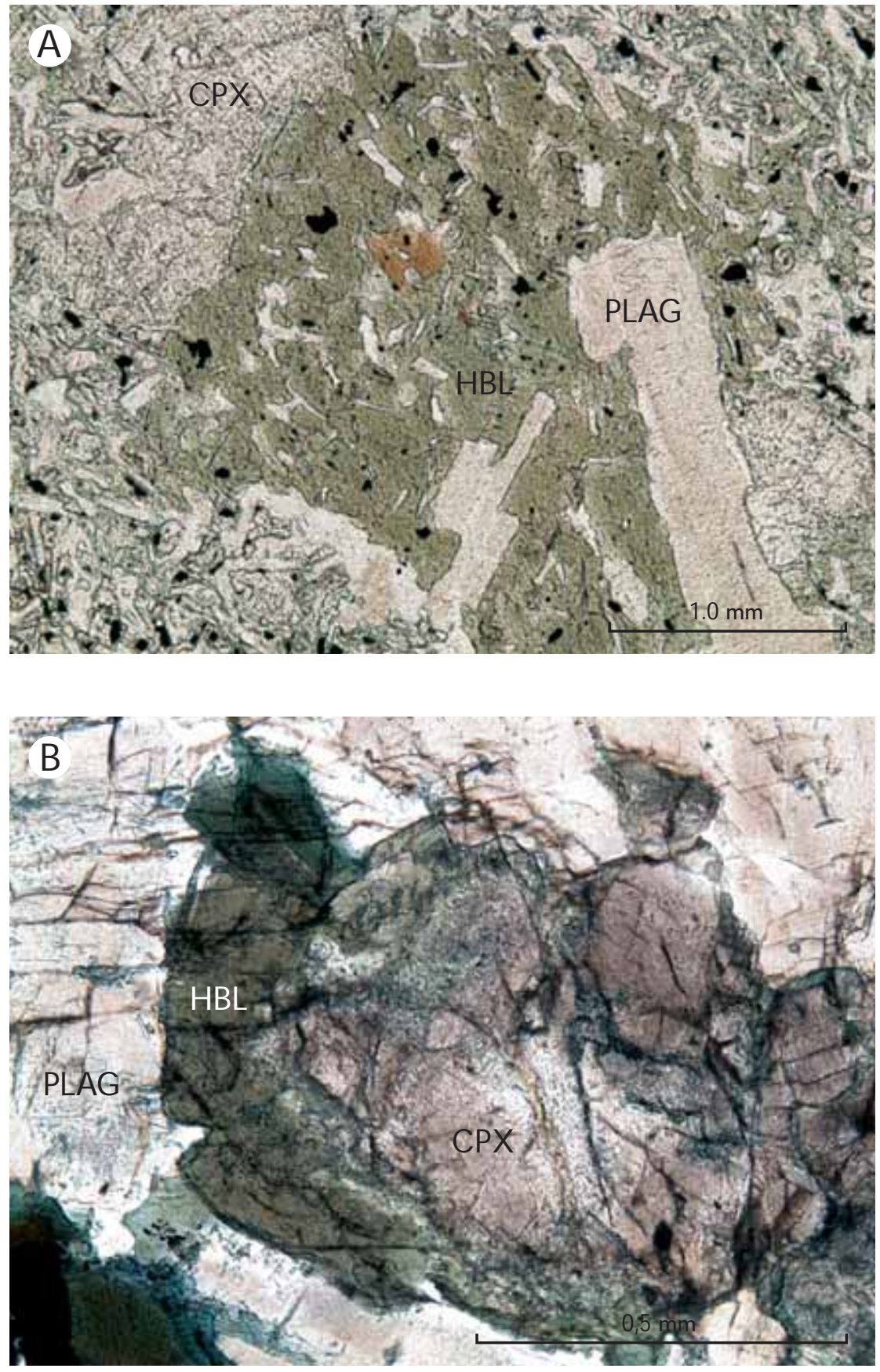

1979). These dykes are weakly foliated and fine-grained (0.1-1.0 mm).

\section{Petrology and geochemistry}

\section{W hole-rock major and trace elements}

A total of 122 dyke samples were analysed for most major and minor elements on fused glass discs using a wave- length dispersive $\mathrm{x}$-ray fluorescence (XRF) spectrometer at the Geological Survey of Denmark and Greenland ( $G E U S$ ) in C openhagen. $\mathrm{N} \mathrm{a}_{2} \mathrm{O}$ was determined by atomic absorption spectrometry. Kystol \& Larsen (1999) describe the analytical methods, precision, and accuracy of the GEUS lab and report that the standard error for all major and minor elements is less than $0.25 \mathrm{wt} \%$, based on multiple analyses of international standards.

Trace element concentrations for 73 dyke samples were measured at the University of California-D avis using a 
Table 1. Major and trace element data for representative Kangâmiut dykes

\begin{tabular}{|c|c|c|c|c|c|c|c|c|c|c|c|c|c|c|c|c|c|c|}
\hline $\begin{array}{l}\text { Sample } \\
\text { Dyke }\end{array}$ & $\begin{array}{c}430904 \\
5\end{array}$ & $\begin{array}{c}430923 \\
13\end{array}$ & $\begin{array}{c}430926 \\
14\end{array}$ & $\begin{array}{c}430931 \\
16\end{array}$ & $\begin{array}{c}430952 \\
27\end{array}$ & $\begin{array}{c}430970 \\
37\end{array}$ & $\begin{array}{c}430981 \\
42\end{array}$ & $\begin{array}{c}430988 \\
45\end{array}$ & $\begin{array}{c}430997 \\
54\end{array}$ & $\begin{array}{c}432102 \\
86\end{array}$ & $\begin{array}{c}432108 \\
60\end{array}$ & $\begin{array}{c}432115 \\
64\end{array}$ & $\begin{array}{c}432118 \\
64\end{array}$ & $\begin{array}{c}432122 \\
64\end{array}$ & $\begin{array}{c}432133 \\
71\end{array}$ & $\begin{array}{c}432138 \\
70\end{array}$ & $\begin{array}{c}432143 \\
76\end{array}$ & $\begin{array}{c}432158 \\
75\end{array}$ \\
\hline $\mathrm{SiO}_{2}$ & 50.87 & 52.78 & 50.64 & 50.73 & 52.19 & 48.90 & 50.71 & 49.30 & 56.06 & 57.18 & 48.97 & 51.01 & 56.84 & 50.25 & 51.00 & 49.46 & 50.57 & 50.48 \\
\hline $\mathrm{TiO}_{2}$ & 2.47 & 2.31 & 1.94 & 0.88 & 1.62 & 1.66 & 1.02 & 1.45 & 0.79 & 1.65 & 1.69 & 1.92 & 2.12 & 1.82 & 1.64 & 2.70 & 1.33 & 1.34 \\
\hline $\mathrm{Al}_{2} \mathrm{O}_{3}$ & 12.62 & 13.65 & 13.29 & 12.57 & 13.19 & 13.14 & 14.09 & 13.34 & 21.46 & 14.37 & 13.75 & 12.97 & 13.07 & 13.67 & 13.96 & 15.57 & 13.14 & 13.59 \\
\hline $\mathrm{Fe}_{2} \mathrm{O}_{3}$ & 4.27 & 3.53 & 4.26 & 1.74 & 4.14 & 2.52 & 1.55 & 1.91 & 1.24 & 2.15 & 4.73 & 2.21 & 1.98 & 2.17 & 2.06 & 2.54 & 1.26 & 1.75 \\
\hline $\mathrm{FeO}$ & 11.67 & 11.34 & 9.99 & 9.10 & 11.05 & 11.98 & 9.89 & 11.40 & 4.34 & 8.94 & 9.48 & 12.73 & 10.99 & 12.22 & 11.59 & 11.51 & 11.99 & 11.84 \\
\hline $\mathrm{MnO}$ & 0.24 & 0.20 & 0.22 & 0.21 & 0.24 & 0.24 & 0.21 & 0.22 & 0.08 & 0.16 & 0.23 & 0.24 & 0.19 & 0.23 & 0.21 & 0.20 & 0.23 & 0.23 \\
\hline $\mathrm{MgO}$ & 4.27 & 3.51 & 5.55 & 8.90 & 4.57 & 6.40 & 7.43 & 6.60 & 0.92 & 2.34 & 6.12 & 5.08 & 2.14 & 5.81 & 4.78 & 3.44 & 6.98 & 6.12 \\
\hline $\mathrm{CaO}$ & 8.93 & 8.24 & 9.86 & 12.31 & 8.48 & 10.85 & 11.27 & 11.39 & 9.07 & 6.11 & 10.72 & 9.46 & 6.17 & 10.12 & 9.53 & 8.61 & 11.40 & 10.59 \\
\hline $\mathrm{Na}_{2} \mathrm{O}$ & 2.47 & 2.91 & 2.55 & 2.27 & 2.80 & 2.28 & 2.15 & 2.25 & 4.19 & 3.69 & 2.44 & 2.57 & 3.37 & 2.45 & 2.46 & 2.99 & 2.11 & 2.07 \\
\hline $\mathrm{K}_{2} \mathrm{O}^{\circ}$ & 0.69 & 1.13 & 0.58 & 0.18 & 0.87 & 0.28 & 0.18 & 0.30 & 0.51 & 1.14 & 0.39 & 0.52 & 1.43 & 0.33 & 0.47 & 1.02 & 0.22 & 0.35 \\
\hline $\mathrm{P}_{2} \mathrm{O}_{5}$ & 0.26 & 0.29 & 0.19 & 0.07 & 0.19 & 0.13 & 0.09 & 0.13 & 0.16 & 0.35 & 0.15 & 0.19 & 0.39 & 0.10 & 0.18 & 0.44 & 0.10 & 0.13 \\
\hline LOI & 0.84 & 0.63 & 0.94 & 0.91 & 1.07 & 1.34 & 0.79 & 1.31 & 0.79 & 1.43 & 1.41 & 1.01 & 1.17 & 0.91 & 1.64 & 1.35 & 1.11 & 1.06 \\
\hline Sum & 99.60 & 100.52 & 100.03 & 99.88 & 100.40 & 99.72 & 99.39 & 99.58 & 99.61 & 99.50 & 100.08 & 99.90 & 99.86 & 100.07 & 99.53 & 99.83 & 100.44 & 99.55 \\
\hline Sc & 38 & 30 & 36 & 58 & 44 & 46 & 47 & 45 & 14 & 20 & 38 & 41 & 22 & 41 & 36 & 29 & 49 & 45 \\
\hline V & 368 & 355 & 333 & 389 & 318 & 381 & 296 & 362 & 29 & 155 & 348 & 393 & 207 & 558 & 303 & 259 & 390 & 336 \\
\hline $\mathrm{Cr}$ & 47 & 14 & 63 & 145 & 43 & 63 & 153 & 98 & 5 & 33 & 134 & 83 & 22 & 94 & 61 & 33 & 174 & 103 \\
\hline $\mathrm{Ni}$ & $4 C$ & 28 & 65 & 113 & 40 & 74 & 88 & 60 & 1 & 17 & 82 & 54 & 15 & 66 & 49 & 23 & 78 & 74 \\
\hline Co & 46 & 44 & 47 & 52 & 44 & 61 & 51 & 56 & 14 & 28 & 53 & 46 & 32 & 54 & 49 & 32 & 53 & 52 \\
\hline $\mathrm{Rb}$ & 22 & 33 & 16 & 3.9 & 25 & 5.6 & 4.3 & 6.1 & 10 & 31 & 7.4 & 13 & 45 & 8.0 & 12 & 28 & 4.6 & 8.5 \\
\hline $\mathrm{Sr}$ & 171 & 201 & 241 & 117 & 207 & 160 & 136 & 160 & 290 & 306 & 235 & 164 & 247 & 164 & 200 & 213 & 138 & 142 \\
\hline Y & 47 & 34 & 29 & 19 & 35 & 27 & 18 & 27 & 34 & 35 & 26.2 & 37 & 48 & 23 & 30 & 53 & 24 & 28 \\
\hline $\mathrm{Zr}$ & 182 & 168 & 139 & 47 & 133 & 99 & 46 & 92 & 157 & 194 & 106 & 133 & 326 & 78 & 110 & 200 & 58 & 84 \\
\hline $\mathrm{Nb}$ & 14.7 & 10.9 & 11.8 & 3.3 & 9.2 & 9.2 & 3.2 & 8.2 & 11.3 & 18.1 & 9.3 & 10.0 & 23.9 & 6.2 & 7.3 & 15.8 & 4.6 & 5.2 \\
\hline $\mathrm{Ba}$ & 204 & 321 & 156 & 50 & 306 & 90 & 50 & 95 & 192 & 392 & 104 & 145 & 454 & 98 & 156 & 366 & 69 & 106 \\
\hline La & 17.5 & 20.5 & 17.1 & 4.4 & 12.7 & 9.2 & 4.4 & 8.4 & 12.3 & 27.8 & 10.86 & 12.9 & 42.0 & 7.4 & 11.4 & 18.2 & 5.8 & 7.6 \\
\hline $\mathrm{Ce}$ & 43.8 & 46.0 & 40.2 & 10.6 & 31.9 & 21.8 & 10.7 & 20.7 & 32.0 & 63.9 & 26.28 & 30.6 & 94.4 & 18.1 & 26.7 & 40.4 & 14.1 & 18.0 \\
\hline $\mathrm{Pr}$ & 6.07 & 6.13 & 5.41 & 1.49 & 4.43 & 3.10 & 1.70 & 3.00 & 4.54 & 8.66 & 3.73 & 4.36 & 11.96 & 2.58 & 3.83 & 5.58 & 2.07 & 2.67 \\
\hline $\mathrm{Nd}$ & 27.8 & 27.1 & 22.7 & 7.37 & 18.8 & 14.2 & 7.31 & 13.9 & 20.6 & 36.2 & 16.93 & 19.1 & 49.7 & 11.6 & 17.3 & 25.7 & 9.90 & 12.2 \\
\hline $\mathrm{Sm}$ & 7.14 & 6.11 & 5.44 & 2.45 & 4.58 & 3.93 & 2.32 & 3.71 & 5.09 & 8.12 & 4.35 & 5.05 & 10.85 & 3.02 & 4.71 & 6.91 & 2.72 & 3.24 \\
\hline Eu & & & & 0.82 & & & 0.89 & 122 & 1.88 & 2.49 & 1.45 & 1.68 & 2.93 & 1.10 & 1.47 & 2.20 & 1.02 & 1.20 \\
\hline $\mathrm{Gd}$ & 7.52 & 6.84 & 5.55 & 3.01 & 5.42 & 4.51 & 2.76 & 4.16 & 5.41 & 6.98 & 4.46 & 5.27 & 10.02 & 3.51 & 4.86 & 7.39 & 3.27 & 3.99 \\
\hline $\mathrm{Tb}$ & 1.33 & 1.12 & 0.87 & 0.51 & 0.95 & 0.79 & 0.50 & 0.7 & 0.90 & 1.11 & 0.75 & 0.99 & 1.4 & 0.60 & 0.82 & 1.32 & 0.57 & 0.68 \\
\hline Dy & 8.17 & 6.80 & 5.22 & 3.12 & 5.63 & 4.61 & 3.1 & 4.3 & 5.44 & 6.31 & 4.47 & 6.23 & 8.2 & 3.75 & 5.01 & 8.5 & 3.68 & 4.51 \\
\hline $\mathrm{Ho}$ & 1.62 & 1.28 & 1.06 & 0.68 & 1.22 & 0.99 & 0.69 & 0.93 & 1.15 & 1.20 & 0.98 & 1.24 & 1.60 & 0.81 & 1.08 & 1.88 & 0.82 & 1.04 \\
\hline $\mathrm{Er}$ & 4.76 & 3.73 & 2.96 & 1.90 & 3.39 & 2.75 & 2.12 & 2.5 & 3.23 & 3.19 & 2.4 & 3.71 & 4.2 & 2.28 & 2.92 & 5.03 & 2.36 & 2.89 \\
\hline $\mathrm{Tm}$ & & 0.52 & 0.42 & 0.30 & 0.5 & 0.42 & 0.2 & 0.3 & 0.48 & 0.45 & 0.3 & 0.57 & 0.6 & 0.34 & 0.41 & 0.7 & 0.36 & 0.41 \\
\hline$Y b$ & 4.52 & 3.34 & 2.67 & 1.97 & 3.53 & 2.61 & 1.96 & 2.54 & 3.11 & 2.89 & 2.31 & 3.45 & 3.90 & 2.20 & 2.67 & 4.97 & 2.31 & 2.81 \\
\hline Lu & 0.63 & 0.49 & 0.39 & 0.29 & 0.54 & 0.42 & 0.29 & 0.37 & 0.45 & 0.4 & 0.3 & 0.5 & 0.55 & 0.32 & 0.43 & 0.74 & 0.35 & 0.41 \\
\hline $\mathrm{Hf}$ & 4.78 & 4.60 & 3.68 & 1.27 & 3.54 & 2.77 & 1.44 & 2.47 & 4.13 & 4.68 & 2.83 & 3.49 & 7.64 & 2.10 & 2.78 & 5.19 & 1.59 & 2.36 \\
\hline $\mathrm{Ta}$ & 1.03 & 0.76 & 0.82 & 0.26 & 0.64 & 0.54 & 0.24 & 0.52 & 0.72 & 1.27 & 0.64 & 0.66 & 1.5 & 0.41 & 0.50 & 0.98 & 0.30 & 0.34 \\
\hline $\mathrm{Pb}$ & 4.04 & 5.81 & 3.26 & 1.49 & 6.50 & 1.8 & 1.08 & 3.3 & 3.78 & 3.6 & 1.9 & 2.6 & 4.8 & 1.73 & 3.07 & 6.66 & 1.03 & 1.88 \\
\hline Th & 2.83 & 3.80 & 2.12 & 0.50 & 3.47 & 0.90 & 0.42 & 0.90 & 1.88 & 4.52 & 1.19 & 1.73 & 7.92 & 1.00 & 1.61 & 3.88 & 0.60 & 1.04 \\
\hline U & 0.71 & 0.93 & 0.54 & 0.14 & 0.79 & 0.24 & 0.11 & 0.24 & 0.49 & 1.10 & 0.29 & 0.46 & 1.92 & 0.28 & 0.40 & 0.87 & 0.16 & 0.29 \\
\hline
\end{tabular}

Major element oxides in wt\%; trace elements in ppm. Sample numbers refer to GEUS databases. Dyke localities shown in Fig.A 1 (appendix).

Perkin-EImer ELAN 500 inductively coupled plasma mass spectrometer (ICP-M S). Samples were prepared for analyses using the method described by Jenner et al. (1990) with the exception that we utilised microwave digestion bombs to insure total dissolution.

Table 1 presents representativemajor and trace element data for the Kangâmiut dykes, and Figs 4 and 5 show these data in covariation diagrams. The full data set is availableupon request from thefirstauthor. TheK angâmiut dykes cover a range from $9.0-0.9$ wt $\% \mathrm{M} \mathrm{gO}$ and the majority of the dykes would be classified as medium-K basalts or low-K basalts based on their $\mathrm{K}_{2} \mathrm{O}$ and $\mathrm{SiO}_{2}$ contents (Le M aitre 2002). First order observations of the major and compatible trace element data, as described below, indicate that the differentiation of the parental magma(s) of the Kangâmiut dykes was influenced by the fractionation of plagioclase, clinopyroxene, late stage Fe Ti oxides and possibly olivine. First order observations based on covariation diagrams neither support nor refute the involvement of hornblende as a fractionating phase.

Figure $4 \mathrm{C}$ shows $\mathrm{Al}_{2} \mathrm{O}_{3}$ concentrations that range between 11.4 and $15.8 \mathrm{wt} \%$. The highest $\mathrm{MgO}$ sample has a low $\mathrm{Al}_{2} \mathrm{O}_{3}$ concentration, whereas the next group of dykes at c. 7.0-7.5 wt\% $\mathrm{M}$ go have higher concentrations of $\mathrm{Al}_{2} \mathrm{O}_{3}$. This increase of $\mathrm{Al}_{2} \mathrm{O}_{3}$ between $\mathrm{C} .9$ and $7 \mathrm{wt} \%$ $\mathrm{M} \mathrm{gO}$ likely reflects olivineand/or clinopyroxene fractionation. Clustering of data between 7.5 and $4.5 \mathrm{wt} \% \mathrm{M}$ gO defines a trend of decreasing $\mathrm{Al}_{2} \mathrm{O}_{3}$ with decreasing $\mathrm{M} \mathrm{gO}$, indicative of plagioclasefractionation. The initial increase in total $\mathrm{FeO}\left(\mathrm{FeO}+0.9 \times \mathrm{Fe}_{2} \mathrm{O}_{3}\right.$ ) between $\mathrm{c} .8 .0$ and 4.5 
Fig. 4. Variations of $\mathrm{SiO}_{2}, \mathrm{TiO}_{2}, \mathrm{Al}_{2} \mathrm{O}_{3^{\prime}}$ $\mathrm{FeO}, \mathrm{CaO}, \mathrm{Na}_{2} \mathrm{O}, \mathrm{K}_{2} \mathrm{O}, \mathrm{P}_{2} \mathrm{O}_{5}$ with $\mathrm{M} \mathrm{gO}$ (in wt\%) for the Kangâmiut dykes. All analyses are recalculated on an anhydrous basis with all iron as $\mathrm{FeO}$.
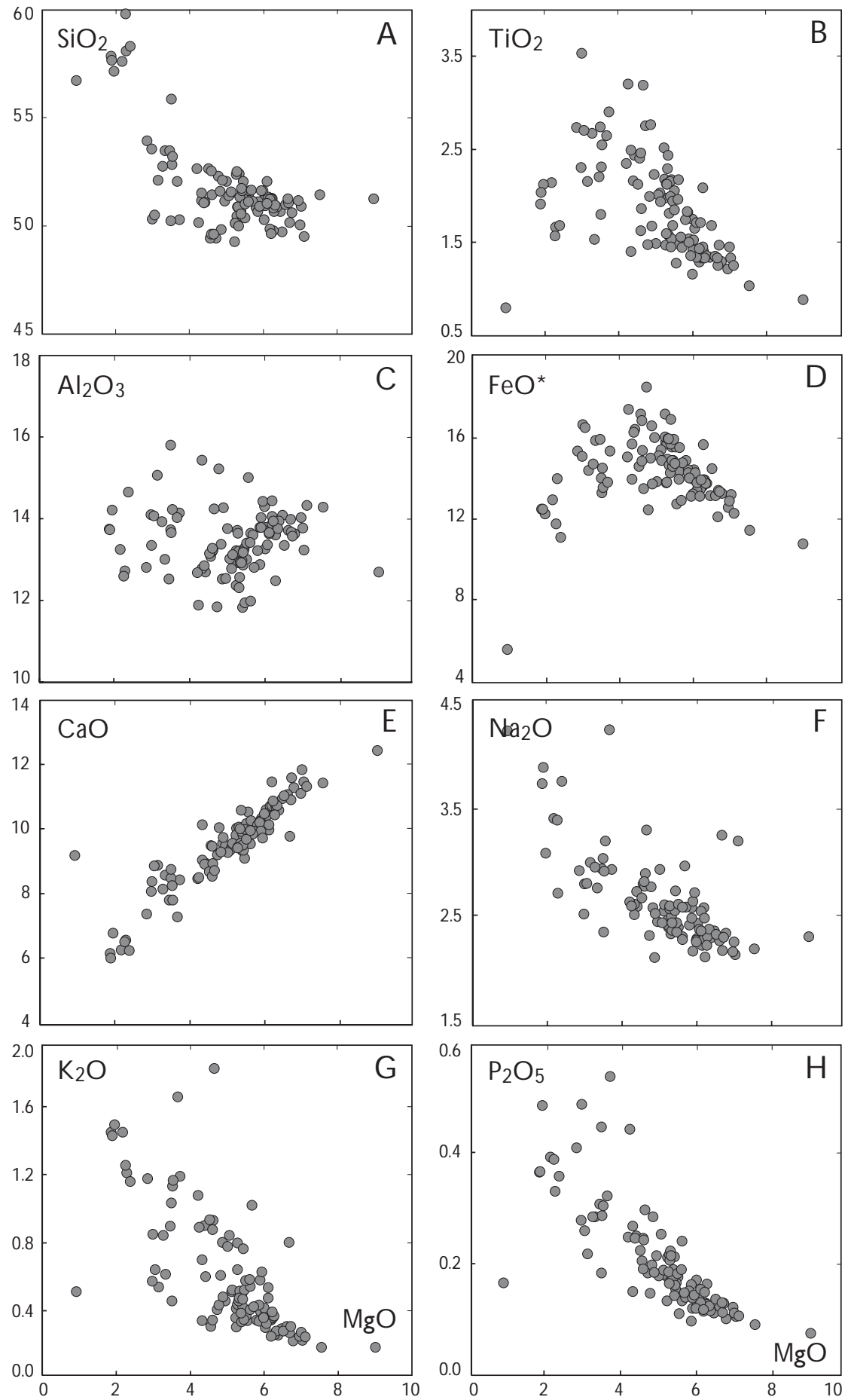

wt $\% \mathrm{M} \mathrm{gO}$ is also indicative of plagioclase fractionation (Fig. 4D).

Figure $4 \mathrm{E}$ shows that $\mathrm{CaO}$ ranges from 12.4 to 6.0 wt $\%$ and correlates positively with $\mathrm{M} \mathrm{gO}$, indicating that clinopyroxene and/or plagioclase was part of the fractionating assemblage. Figure 6 shows the $\mathrm{CaO} / \mathrm{Al}_{2} \mathrm{O}_{3}$ ratio for the K angâmiut dykes decreases with decreasing $\mathrm{M}$ go , and Fig. 5A shows decreasing Sc with increasing Zr. Both of these observations further indicate that clinopyroxene was a fractionating phase. The decrease in nickel with increasing zirconium, shown in Fig. 5C, is related to clinopyroxene and/or olivine fractionation.

Figure 4B shows $\mathrm{TiO}_{2}$ concentrations that range from 0.9-3.5 wt\% with trends that show increasing $\mathrm{TiO}$ from 9-4.5 wt\% M gO that changes to decreasing $\mathrm{T} \mathrm{iO}_{2}$ below c. $4.5 \mathrm{wt} \% \mathrm{M} \mathrm{gO}$. Figure 4D shows that a similar trend is 

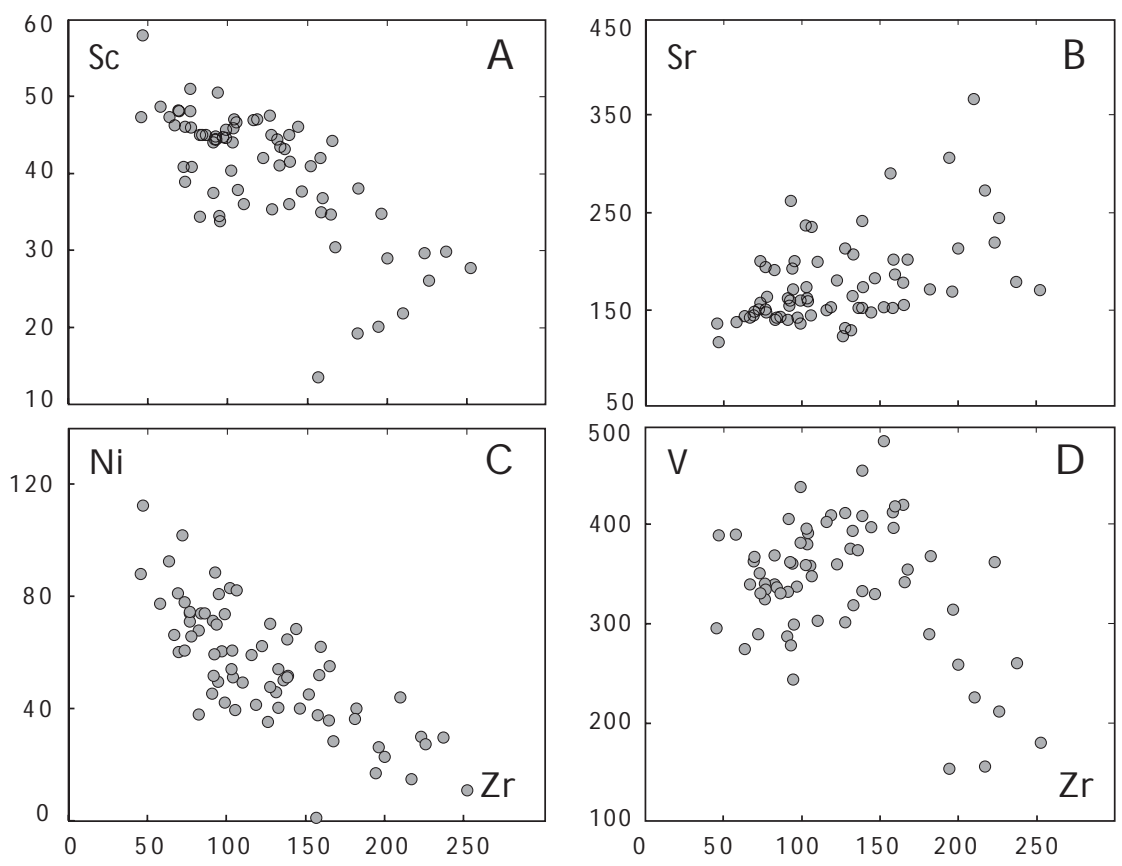

Fig. 5. Variation of Sc, Sr, $\mathrm{Ni}$, and $\mathrm{V}$ with $\mathrm{Zr}$ (in ppm) for the Kangâmiut dykes.

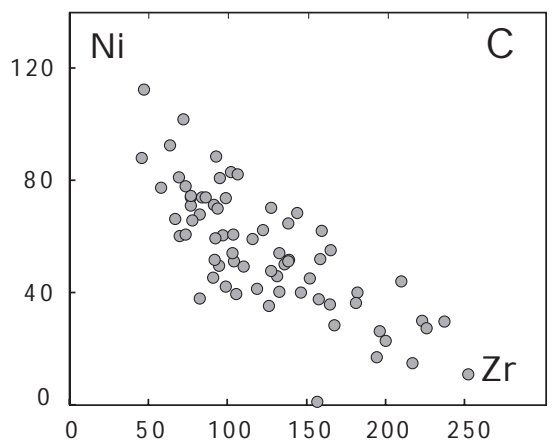

observed for total FeO . Additionally, vanadium (Fig. 5D ) shows an initial increase, then decrease with increasing zirconium. These changes from increasing to decreasing $\mathrm{TiO}_{2}, \mathrm{FeO}$ and vanadium concentrations suggest $\mathrm{Fe} \mathrm{Ti}$ oxides fractionated when the magmas reached c. $4.5 \mathrm{wt} \%$ $\mathrm{MgO}$.

\section{Mineral chemistry}

$M$ ajor element compositions of pyroxenes, plagioclase, and hornblende were acquired using a C ameca SX-50 microprobeat the University of $C$ alifornia- $D$ avis. Analyses were

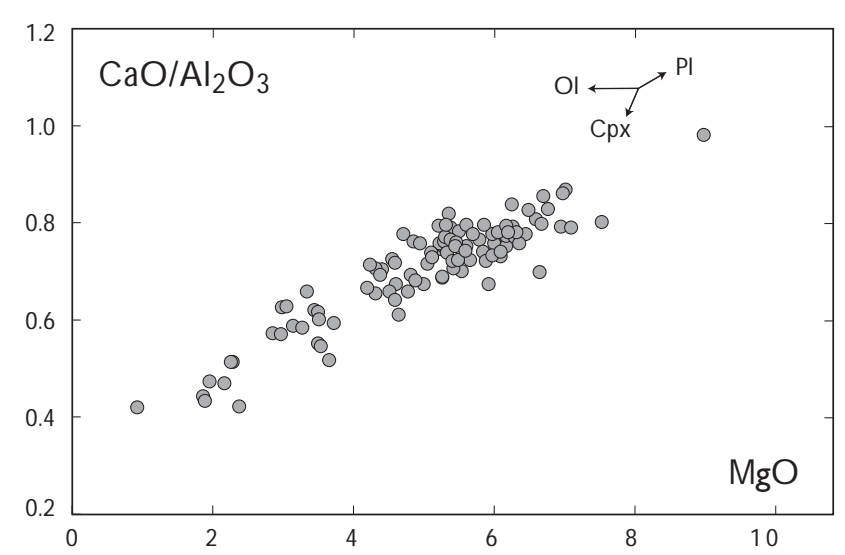

Fig. 6. Variation of $\mathrm{CaO} / \mathrm{Al}_{2} \mathrm{O}_{3}$ with $\mathrm{MgO}$. Arrows show path caused by fractionation of olivine, clinopyroxene, or plagioclase from a starting composition with 9 wt $\% \mathrm{MgO}$ and $\mathrm{Ca} / \mathrm{Al}_{2} \mathrm{O}_{3}=1.0$. made using a $15 \mathrm{kV}$ accelerating voltage, a $10 \mathrm{nA}$ beam current, and a $1 \mu \mathrm{m}$ beam. Elements were calibrated using mineral standards. The data in Tables 2-4 give the compositions of clinopyroxene, plagioclase, and hornblende phenocrysts from chilled margins.

Table 2 presents major and minor element compositions of clinopyroxene phenocrysts from chilled margins based on the average of 2-4 spot analyses of 4-7 grains per sample. The proportions of enstatite, ferrosilite, and wollastonite components are $0.48-0.52,0.13-0.23$, and $0.28-0.35$, respectively. $\mathrm{Al}_{2} \mathrm{O}_{3}$ concentrations range from $3.93-2.75 \mathrm{wt} \%$, while $\mathrm{N}_{2} \mathrm{O}$ variesfrom $0.36-0.26 \mathrm{wt} \%$.

Table 3 presents plagioclase phenocryst compositions from chilled margins. Plagioclase phenocryst cores have an anorthite (An) component range of $A n_{69}-A_{55}$. Table 4 presents compositions of the hornblendes found in the chilled margins of some Kangâmiut dykes. They would be classified as ferrohornblende and ferrotschermakite based on the classification of Leake et al. (1997).

\section{W hole-rock and mineral compositions in projection space}

Figure 7 shows pseudo-ternary projections of whole-rock and mineral data for the Kangâmiut dykes. The components CPX, PLAG , OL, and QTZ were calculated using major and minor elements and the scheme of Tormey et al. (1987). In the projection from QTZ (Fig. 7A), the dyke data form a cluster that is displaced from the centre 
Table 2. Microprobe analyses of clinopyroxene phenocrysts from chilled margins

\begin{tabular}{|c|c|c|c|c|c|c|c|c|}
\hline $\begin{array}{l}\text { Sample } \\
\text { Dyke }\end{array}$ & $\begin{array}{c}430988 \\
45 \\
n=7\end{array}$ & $\begin{array}{c}432108 \\
60 \\
\mathrm{n}=8\end{array}$ & $\begin{array}{c}432145 \\
76 \\
n=6\end{array}$ & $\begin{array}{c}432148 \\
77 \\
\mathrm{n}=8\end{array}$ & $\begin{array}{c}832158 \\
75 \\
n=8\end{array}$ & $\begin{array}{c}430211 \\
82 \\
n=8\end{array}$ & $\begin{array}{c}430267 \\
84 \\
\mathrm{n}=10\end{array}$ & $\begin{array}{c}430283 \\
85 \\
n=10\end{array}$ \\
\hline $\mathrm{SiO}_{2}$ & 52.34 & 50.68 & 51.88 & 51.17 & 52.01 & 51.36 & 51.85 & 51.59 \\
\hline $\mathrm{TiO}_{2}$ & 0.47 & 0.65 & 0.44 & 0.61 & 0.45 & 0.34 & 0.44 & 0.60 \\
\hline $\mathrm{Al}_{2} \mathrm{O}_{3}$ & 3.17 & 3.93 & 3.14 & 3.21 & 3.34 & 2.75 & 3.63 & 2.68 \\
\hline $\mathrm{Cr}_{2} \mathrm{O}_{3}$ & 0.11 & 0.19 & 0.18 & 0.21 & 0.22 & 0.08 & 0.18 & 0.07 \\
\hline $\mathrm{FeO}$ & 8.29 & 9.83 & 8.76 & 12.45 & 9.43 & 13.79 & 9.72 & 12.94 \\
\hline $\mathrm{MgO}$ & 16.46 & 15.18 & 15.70 & 15.62 & 15.54 & 16.94 & 15.62 & 15.37 \\
\hline $\mathrm{CaO}$ & 19.59 & 19.18 & 18.96 & 16.16 & 19.01 & 14.32 & 18.01 & 16.52 \\
\hline $\mathrm{Na}_{2} \mathrm{O}$ & 0.29 & 0.32 & 0.26 & 0.29 & 0.28 & 0.36 & 0.31 & 0.26 \\
\hline Sum & 100.72 & 99.96 & 99.31 & 99.72 & 100.28 & 99.94 & 99.76 & 100.03 \\
\hline $\mathrm{Si}$ & 1.917 & 1.886 & 1.927 & 1.913 & 1.920 & 1.922 & 1.920 & 1.928 \\
\hline $\mathrm{Al}(\mathrm{IV})$ & 0.083 & 0.114 & 0.073 & 0.087 & 0.080 & 0.078 & 0.080 & 0.072 \\
\hline $\mathrm{Al}(\mathrm{VI})$ & 0.053 & 0.058 & 0.065 & 0.055 & 0.065 & 0.074 & 0.079 & 0.046 \\
\hline $\mathrm{Ti}$ & 0.013 & 0.018 & 0.012 & 0.017 & 0.012 & 0.011 & 0.012 & 0.017 \\
\hline $\mathrm{Cr}$ & 0.003 & 0.006 & 0.005 & 0.006 & 0.007 & 0.001 & 0.005 & 0.002 \\
\hline $\mathrm{Fe}^{3+*}$ & 0.022 & 0.039 & 0.000 & 0.013 & 0.004 & 0.016 & 0.000 & 0.010 \\
\hline $\mathrm{Fe}^{2+}$ & 0.232 & 0.266 & 0.274 & 0.377 & 0.287 & 0.401 & 0.308 & 0.395 \\
\hline$M n$ & 0.000 & 0.000 & 0.000 & 0.000 & 0.000 & 0.000 & 0.000 & 0.000 \\
\hline $\mathrm{Mg}$ & 0.899 & 0.842 & 0.870 & 0.871 & 0.855 & 0.858 & 0.862 & 0.856 \\
\hline $\mathrm{Ca}$ & 0.768 & 0.765 & 0.755 & 0.647 & 0.752 & 0.611 & 0.715 & 0.661 \\
\hline $\mathrm{Na}$ & 0.021 & 0.025 & 0.020 & 0.021 & 0.020 & 0.036 & 0.022 & 0.019 \\
\hline$\Lambda$ & 0.000 & 0.000 & 0.000 & 0.000 & 0.000 & 0.000 & 0.000 & 0.000 \\
\hline Total & 4.011 & 4.020 & 4.001 & 4.006 & 4.002 & 4.008 & 3.996 & 4.005 \\
\hline $\mathrm{Mg} \#$ & 0.78 & 0.73 & 0.76 & 0.69 & 0.75 & 0.67 & 0.74 & 0.68 \\
\hline Wo & 0.35 & 0.34 & 0.35 & 0.29 & 0.34 & 0.28 & 0.33 & 0.30 \\
\hline En & 0.52 & 0.51 & 0.50 & 0.50 & 0.49 & 0.49 & 0.50 & 0.48 \\
\hline Fs & 0.13 & 0.16 & 0.16 & 0.22 & 0.17 & 0.23 & 0.18 & 0.22 \\
\hline
\end{tabular}

0 xides in wt\%; $n=$ number of grains. Fe ${ }^{3+*}$ calculated using the method of Papike et al. (1974). Dyke localities shown in Fig. A 1 (appendix).

of the ternary plot towards the PLAG apex. In this projection all the dykes lie within the phase volumes defined by thejoins between olivine, clinopyroxeneand plagioclase (Ol:C px:PI) or hornblende, clinopyroxeneand plagioclase (H bl:C px:Pl). In the projection from the CPX component (Fig. 7B), the dykes define an array that projects away from both the PI:OI and the PI:H bl joins. Similarly, in the projection from the PLAG component (Fig. 7C), the dykes form an array that intersects both the $\mathrm{Cpx}: \mathrm{OI}$ and C px:H bl joins. These observations show that plagioclase, clinopyroxene and either olivine or hornblende were cofractionating phases.

$\mathrm{A}$ and $\mathrm{C}$ in Fig. 7 also show experimentally determined $1 \mathrm{~atm}$ and $0.8 \mathrm{G} \mathrm{PaO} \mathrm{O}: \mathrm{Cpx}: \mathrm{PI}$ cotectics derived from melting experiments using a primitive K angâmiut dyke (dyke \#45) as thestarting material ( $M$ ayborn 2000). Thewholerock data form a cluster near the low pressure $0 \mathrm{I}: \mathrm{Cpx}: \mathrm{PI}$ cotectic in the projection from the Q T Z component. Similarly, in the projection from the PLAG component the whole-rock data also plot close to the low-pressure cotectic.
Table 3. Microprobe analyses of plagioclase phenocrysts from chilled margins

\begin{tabular}{lcccccc}
\hline Sample & 430988 & 432108 & 432145 & 432148 & 432158 & 430211 \\
Dyke & 45 & 60 & 76 & 77 & 75 & 82 \\
& $\mathrm{n}=8$ & $\mathrm{n}=8$ & $\mathrm{n}=8$ & $\mathrm{n}=8$ & $\mathrm{n}=7$ & $\mathrm{n}=8$ \\
\hline $\mathrm{SiO}_{2}$ & 52.18 & 49.74 & 53.36 & 53.79 & 51.23 & 54.13 \\
$\mathrm{Al}_{2} \mathrm{O}_{3}$ & 30.45 & 31.49 & 29.65 & 29.65 & 30.91 & 29.03 \\
$\mathrm{FeO}$ & 0.65 & 0.57 & 0.59 & 0.74 & 0.96 & 0.92 \\
$\mathrm{CaO}$ & 13.11 & 14.13 & 12.43 & 12.23 & 13.34 & 11.24 \\
$\mathrm{Na}_{2} \mathrm{O}$ & 4.02 & 3.36 & 4.33 & 4.64 & 3.89 & 4.84 \\
$\mathrm{~K}_{2} \mathrm{O}$ & 0.05 & 0.05 & 0.09 & 0.07 & 0.09 & 0.17 \\
$\mathrm{Sum}$ & 100.46 & 99.34 & 100.45 & 101.12 & 100.41 & 100.34 \\
& & & & & & \\
$\mathrm{Ab}$ & 35 & 30 & 38 & 40 & 34 & 43 \\
$\mathrm{An}$ & 64 & 69 & 61 & 59 & 65 & 55 \\
Or & 0.3 & 0.3 & 0.5 & 0.4 & 0.5 & 1.0 \\
\hline Oxides in wt\%; $\mathrm{n}=$ number of grains. Dyke localities shown in Fig. A1 \\
(appendix).
\end{tabular}

\section{Incompatible trace element behaviour}

Figure 8 shows representative chondrite normalised rareearth element (REE) patterns for the Kangâmiut dykes. The dykes are slightly light rare-earth element (LREE) enriched with $\mathrm{a} \mathrm{L} a / \mathrm{Sm}_{N}$ ratio ranging from 1.16 to 2.50 , with an average of 1.50. The heavy rare earth (HREE) patterns have shallow slopes with $\mathrm{D} D \mathrm{y} / \mathrm{Yb}_{\mathrm{N}}$ range of 1.05

Table 4. Microprobe analyses of amphiboles from chilled margins

\begin{tabular}{lccc}
\hline Sample & 432158 & 430267 & 430283 \\
Dyke & 75 & 84 & 85 \\
& $\mathrm{n}=12$ & $\mathrm{n}=14$ & $\mathrm{n}=6$ \\
\hline $\mathrm{SiO}_{2}$ & 43.90 & 42.63 & 40.88 \\
$\mathrm{TiO}_{2}$ & 1.04 & 1.92 & 1.64 \\
$\mathrm{Al}_{2} \mathrm{O}_{3}$ & 10.69 & 10.05 & 9.98 \\
$\mathrm{FeO}$ & 21.09 & 21.73 & 24.02 \\
$\mathrm{MnO}$ & 0.22 & 0.19 & 0.21 \\
$\mathrm{MgO}$ & 8.09 & 8.05 & 6.44 \\
$\mathrm{CaO}$ & 10.93 & 10.78 & 10.58 \\
$\mathrm{Na} \mathrm{a}_{2} \mathrm{O}$ & 1.18 & 1.63 & 1.58 \\
$\mathrm{~K} 2 \mathrm{O}$ & 0.99 & 0.90 & 0.90 \\
$\mathrm{Cl}$ & 0.57 & 0.67 & 0.65 \\
$\mathrm{~F}$ & 0.09 & 0.05 & 0.14 \\
$\mathrm{Sum}$ & 98.79 & 98.60 & 97.02 \\
& & & \\
$\mathrm{Si}$ & 6.549 & 6.425 & 6.346 \\
$\mathrm{Ti}$ & 0.117 & 0.218 & 0.192 \\
$\mathrm{Al}(\mathrm{IV})$ & 1.451 & 1.575 & 1.654 \\
$\mathrm{Al}(\mathrm{VI})$ & 0.427 & 0.209 & 0.172 \\
$\mathrm{Fe} 3+$ & 0.767 & 0.799 & 0.922 \\
$\mathrm{Fe} 2+$ & 1.864 & 1.940 & 2.196 \\
$\mathrm{Mn}$ & 0.027 & 0.025 & 0.027 \\
$\mathrm{Mg}$ & 1.798 & 1.809 & 1.491 \\
$\mathrm{Ca}$ & 1.747 & 1.741 & 1.760 \\
$\mathrm{Na}(\mathrm{M} 4)$ & 0.253 & 0.259 & 0.240 \\
$\mathrm{Na}(\mathrm{a})$ & 0.089 & 0.217 & 0.237 \\
$\mathrm{~K}(\mathrm{a})$ & 0.189 & 0.172 & 0.178 \\
$\mathrm{Total}$ & 15.28 & 15.39 & 15.41 \\
\hline $\mathrm{O}$ xides, & 0.39 & \\
\hline
\end{tabular}

0 xides, $\mathrm{Cl}$ and $\mathrm{F}$ in wt\%. Dyke localities shown in Fig. A 1 (appendix), 

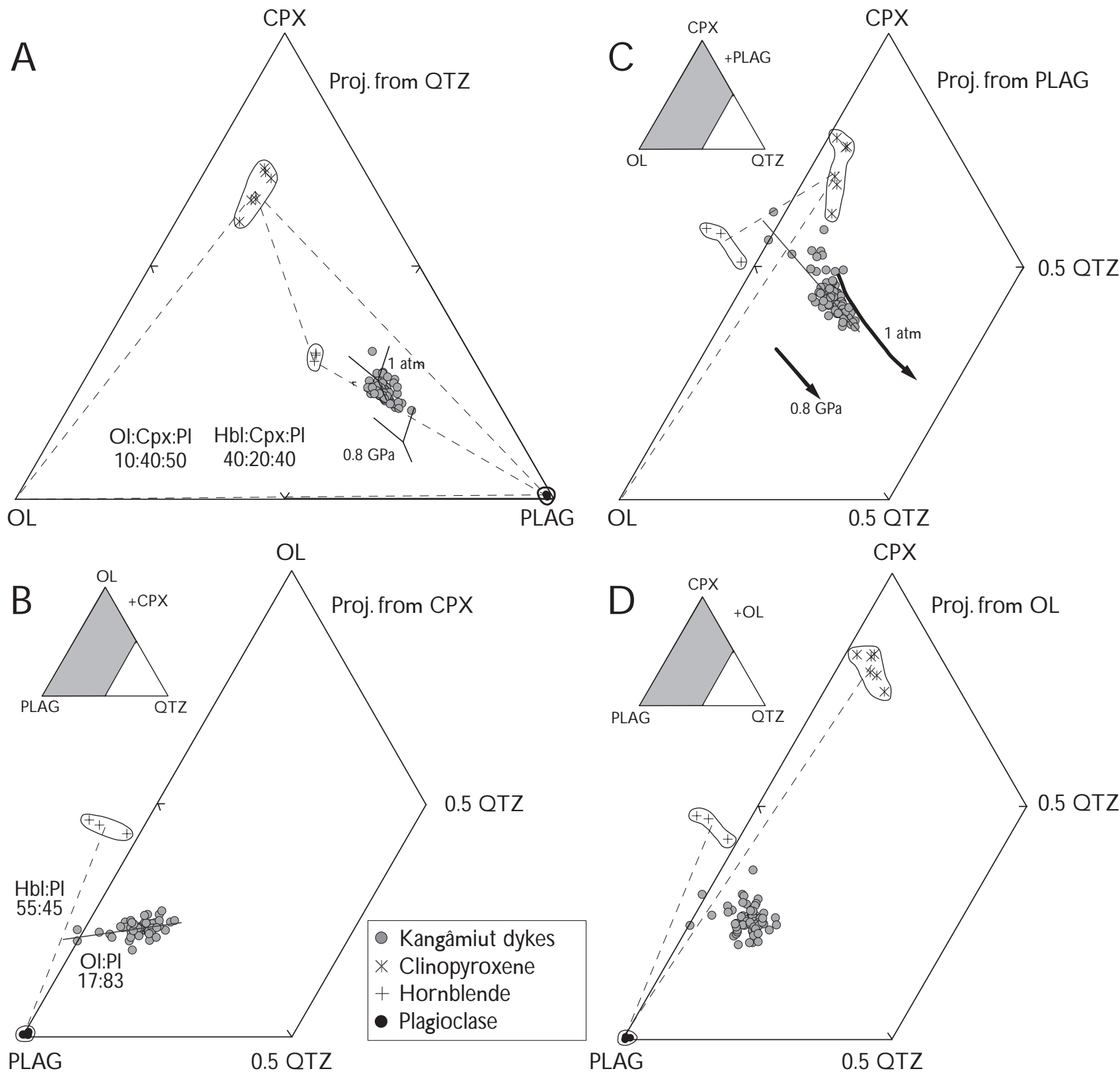

Fig. 7. Pseudo-ternary projections of whole-rock and mineral compositions from the Kangâmiut dykes using the projection scheme of Tormey et al. (1987). D ashed lines connect possible crystal lisation assemblages. Solid lines through data show the trend of Kangâmiut dykes where this is well defined, and the locations of the olivine:clinopyroxene:plagioclase cotectics at $0.8 \mathrm{GPa}$ and $1 \mathrm{~atm}$. A: Projection from the QTZ component. B: Projection from the CPX component. C: Projection from the PLAG component. D : Projection from the $\mathrm{L}$ component.

to 1.46 and an average of 1.15 . The two most LREEenriched samples come from sheared dioritic centres and have $\mathrm{D} y / Y b_{N}$ ratios of 1.46 and 1.42 , respectively. The patterns for the sheared dioritic centres cross-cut the patterns for non-sheared dykes.

Figure 9A shows incompatible trace elements for the Kangâmiut dykes on primitive mantle normalised compatibility diagrams (Thompson 1982). The elements on the right hand side of Fig. 9A are moderately incompatible, with incompatibility increasing towards the left using the element order from Sun \& M CD onough (1989). T he most primitive K angâmiut dykes have the lowest concentration of incompatible elements and have flat patterns with small negative $\mathrm{N} \mathrm{b}$ and $\mathrm{Zr}$ anomalies. The negative $\mathrm{Sr}$ anomaly seen in the more evolved samples reflects plagioclase fractionation. The two most evolved samples 


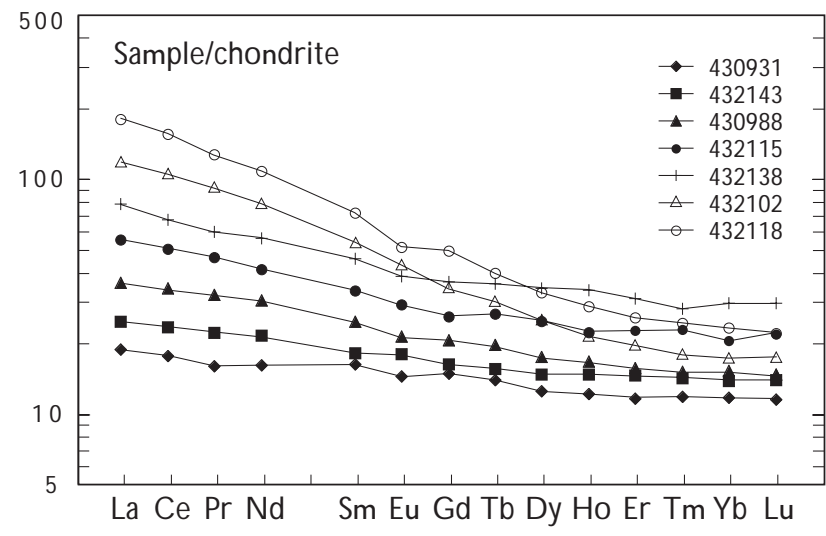

Fig. 8. Rare-earth element compositions of representative Kangâmiut dykes normal ised to $\mathrm{C} 1$ chondrite. Chondrite normal ising values from Sun \& M CDonough (1989).

(432102 and 432118) are sheared dioritic centres and display negative T $\mathrm{i}$ anomalies. They also show a depletion of HREE, as noted in Fig. 8.

Figure 9B shows representative patterns for basalts from a variety of tectonic settings and a pattern representing the average of Kangâmiut dykes with $\mathrm{MgO}>6 \mathrm{wt} \%$. $N$ otable features in the Kangâmiut pattern are a smooth, slightly increasing trend from right to left through the moderately incompatibleelements ( $L$ u to $\mathrm{Sm}$ ), small negative anomalies of $\mathrm{Nb}, \mathrm{Sr}$, and $\mathrm{Zr}$, and a relatively flat trend for $\mathrm{Th}, \mathrm{Ba}$ and $\mathrm{Rb}$. T he Kangâmiut dyke pattern is distinct relative to the ocean island basalt $(O \mid B)$, midocean ridge basalt (M ORB), island arc basalt (IAB), and continental arc basalt (CAB) patterns. For example, the Kangâmiut dykes do not display the enrichment of highly incompatibleelements, or the positive $\mathrm{N} b$ anomaly seen in the O IB pattern, or depletions seen in the M ORB pattern. Relative to $I A B$ and $C A B$, the K angâmiut dyke patterns do not exhibit the large negative $\mathrm{N} b$ anomaly or the positive $\mathrm{Sr}$ anomaly. O verall, the Kangâmiut dyke pattern most closely resembles the pattern for continental flood basalts (CFB), including the shallow slope of the pattern, and the small negative $\mathrm{N} \mathrm{b}$ and $\mathrm{Sr}$ anomalies.

\section{Discussion}

\section{Tectonic setting}

O ne of the primary goals of this study is to constrain the tectonic environment during emplacement of the Kangâmiut dykes. Experimental melting studies over the past 40 years have shown that basalts are products of partial melting of peridotite (Reay \& H arris 1964; Takahashi 1986; Baker \& Stolper 1994). Since the dominant source of peridotite is the mantle, then the basaltic nature of the Kangâmiut dykes indicates that they resulted from partial melting of mantle peridotite followed by intracrustal differentiation. Three settings where mantle melting occurs beneath continental crust are (1) subduction zones, (2) active rifts associated with mantle plumes, and (3) passive rift settings. Each of these settings can have distinctive mantle compositions and conditions for melting
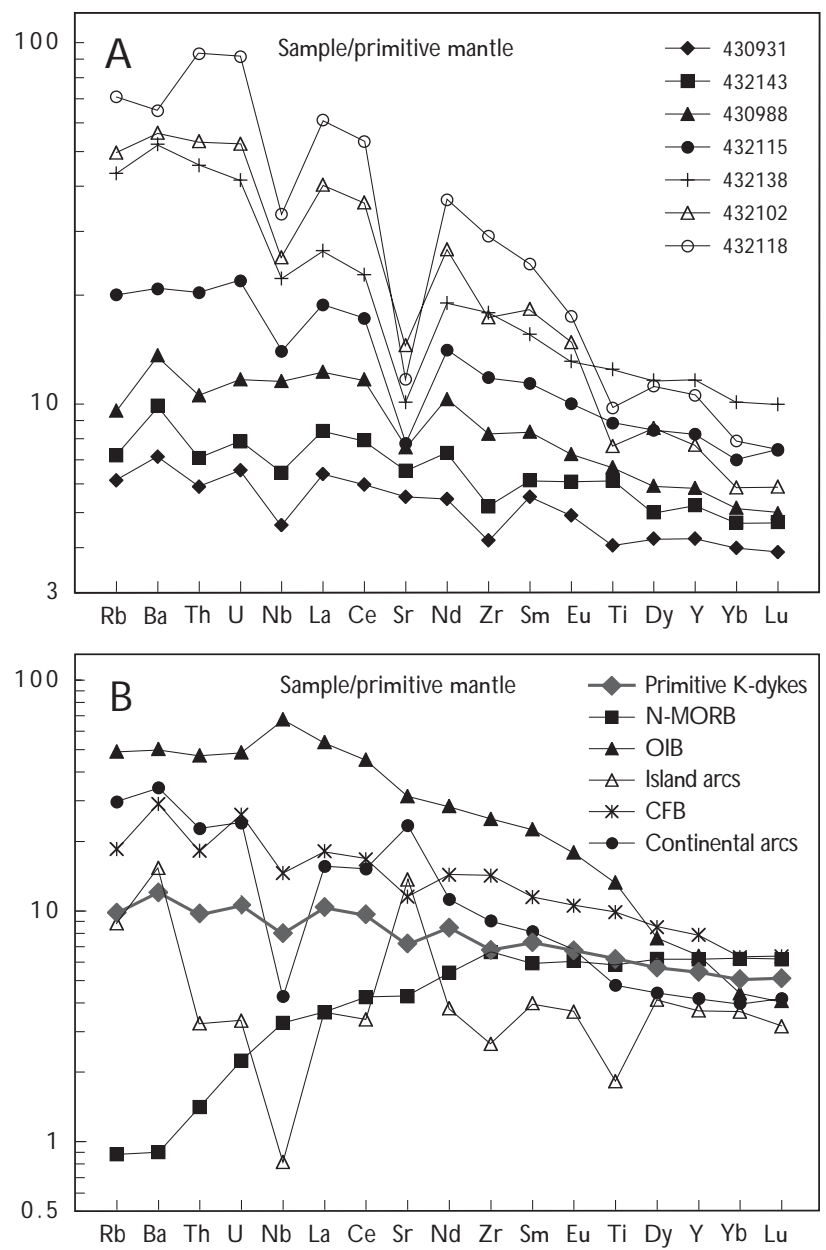

Fig. 9. A: N ormalised incompatibletrace element compositions of representative Kangâmiut dykes. B: C omparison of theKangâmiut dykes with normal mid-ocean ridge basalts (N-M ORB), ocean-island basalts (O IB), island arc basalts, continental flood basalts (CFB), and continental arcs. Representative 'Primitive Kangâmiut dykes' is the average composition of $18 \mathrm{~K}$ angâmiut dykes with a $\mathrm{M}$ gO range of 8.9-6.1 wt\%. Data for N-M ORB and OIB are from Sun \& M CD onough (1989). I sland arc data compiled from Bailey et al. (1989), Pearce et al. (1995), and Gust et al. (1997). CFB data compiled from H ooper \& H awkesworth (1993), Lightfoot et al. (1993), Wooden et al. (1993), Peate \& H awkesworth (1996) and Storey et al. (1997). Continental arc data compiled from Tormey et al. (1991) and Bacon et al. (1997). 


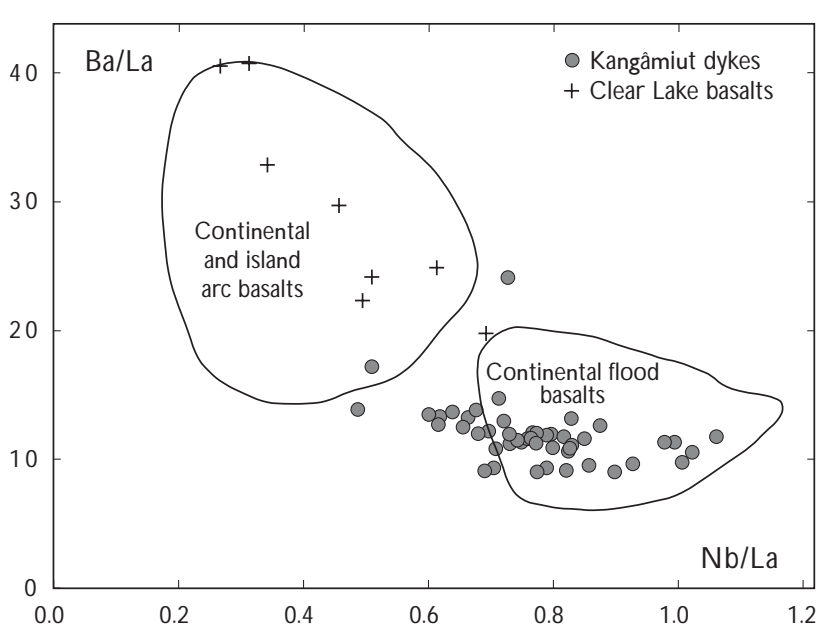

Fig. 10. Ba/La versus $\mathrm{N}$ b/La showing the differences between arc basalts, the K angâmiut dykes, and basalts from the Clear Lake Volcanic Field. Data for the arc field are from Bailey et al. (1989), Tormey et al. (1991), Francalanci et al. (1993), Pearce et al. (1995), Bacon et al. 1997), Gust et al. (1997), and Kelemen et al. (2003). Data for the continental flood basalt field arefrom H ooper \& H awkesworth (1993), Lightfoot et al. (1993), Wooden et al. (1993), Peate \& H awkesworth (1996), and Storey et al. (1997). D ata for the Clear Lake Volcanic Field are from $C$ harles Lesher (unpublished data).

that are reflected in the trace element compositions of the associated basalts.

TheK angâmiut dykes have evolved compositions with a M g-number (defined as $100 \mathrm{M} \mathrm{g/(M} \mathrm{g} \mathrm{+Fe)} \mathrm{on} \mathrm{a} \mathrm{molec-}$ ular basis) range of $0.60-0.21$. M agmas in equilibrium with mantle peridotite will have a $\mathrm{M}$ g-number close to 0.71 (Roeder \& Emslie 1970; Langmuir et al. 1992) showing that even the most primitive Kangâmiut dykes represent somewhat evolved magmas. T hus, the major elements reflect both the fractionation and mantle melting histories. H owever, most incompatible trace element ratios remain relatively constant during crystallisation and can be used to constrain primary source characteristics. The following discussion examines some characteristics of the mantle source and the conditions of mantle melting revealed by examining incompatibletrace elements from the more primitive dyke samples (with $\mathrm{M} \mathrm{gO}>4.5 \mathrm{wt} \%$ ).

\section{Subduction hypothesis for generation of Kangâmiut dykes}

Subduction environments generate basaltic melts by two different mechanisms of partial melting. Thefirst is melting induced by lowering the solidus temperature of the peridotite by the introduction of volatiles from the subducting slab and subsequent decompression melting within the mantle wedge (Jakes \& Gill 1970; Tatsumi 1989; Arculus 1994). The second is decompression melting associ- ated with back-arc spreading (Tatsumi et al. 1989; Gribble et al. 1998). Although the mechanisms of melting in these settings are different from each other, they both produce magmas with a compositional 'subduction component' that is indicative of a hydrated and metasomatised mantle. Someimportant characteristics of subduction zone basalts are H FSE depletions, LILE enrichment, and high $\mathrm{Al}_{2} \mathrm{O}_{3}$. The available data can be used to evaluate the subduction hypothesis for the Kangâmiut dyke swarm implied by Escher et al. (1976) and Bridgwater et al. (1995), and explicitly proposed by Cadman et al. (2001).

As shown in Fig. 9B, arc basalts have distinctive depletions in H FSE. These H FSE depletions occur in Palaeozoic, Proterozoic, and Archaean arc-related basalts, suggesting that modern style subduction occurred in the Archaean (Stern et al. 1994; Blichert-Toft et al. 1995). In addition to H FSE depletions, arc basalts are enriched in LILE (e.g. Pb, K, Ba, Rb, and Cs) relative to basalts from other tectonic settings. This enrichment is proposed to

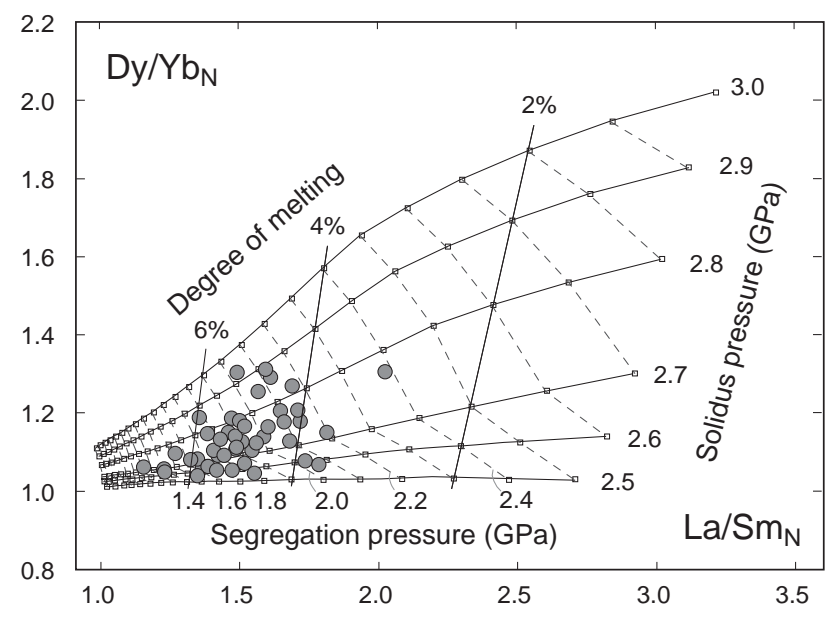

Fig. 11. Chondrite-normalised DyYb versus $\mathrm{La} / \mathrm{Sm}$ ratios for the Kangâmiut dykes and mantle melting models using the al gorithm of Fram \& Lesher (1993) based on a $0.5 \%$ depleted PM source composition, where $F$ is the melt proportion. The model assumes partial melting proceeds by incremental non-modal batch melting at $1 \%$ per kbar of decompression in a corner flow melting regime. M elts are pooled after each kbar of decompression. REE distribution coefficients are taken from $G$ reen (1994). The garnet-spinel transition is modelled as a gradual change between 30 and $25 \mathrm{kbar}$. The spinel-plagioclase transition is modelled as a gradual change between 14 and $10 \mathrm{kbar}$. Residues are recalculated after each melting increment and adjusted for pressure depen dent phase transitions using melting reactions as given by Fram \& Lesher (1993). M odel curves, for melting starting at 3.0, 2.9, 2.8, 2.7, 2.6 and $2.5 \mathrm{GPa}$ and ending at $0.5 \mathrm{GPa}$, define a melting grid, where solid subvertical lines contour constant mean melt fraction, whereas the dashed subvertical lines contour final pooled melt segregation pressure (i.e. the top of the melting column). Slightly modified from Mayborn \& Lesher (2004). 
occurduring theflux of fluids from the slab into themantle wedge (M iller et al. 1994; Pearce et al. 1995; Becker et al. 1999). M afic rock suites in volcanic arc settings al so typically contain a large proportion of high-alumina basalts (Perfit et al. 1980; Brophy \& M arsh 1986; K elemen et al. 2003).

If the Kangâmiut dykes are arc-related, they should show LILE enrichment, H FSE depletions, and high $\mathrm{Al}_{2} \mathrm{O}_{3}$. Figure 10 shows a comparison of the $\mathrm{N} \mathrm{b/La}$ and $\mathrm{Ba} / \mathrm{La}$ ratios for the Kangâmiut dykes, island arcs, continental arcs, and continental flood basalts. Relative to arc basalts, the K angâmiut dykes have lower $\mathrm{Ba} / \mathrm{L}$ a and $\mathrm{N}$ b/La ratios - unlike arc-related basalts. Additionally, subduction zone basaltstypically have $\mathrm{Al}_{2} \mathrm{O}_{3}$ contents of $19-15 \mathrm{wt} \%$ (Plank \& Langmuir 1988, 1992; K elemen et al. 2003), whereas all of the Kangâmiut dykes have lower $\mathrm{Al}_{2} \mathrm{O}_{3}$ concentrations (16-12 wt\%).T hus, the Kangâmiut dykes have none of the geochemical characteristics of subduction related basalts, contrary to previous conjecture (C adman et al. 2001).

A more detailed analysis of the C adman et al. (2001) hypothesis also raises significant questions about its viability. C adman et al. (2001) propose that the Kangâmiut dykes formed after ridge subduction resulting in a 'slab window' passing beneath metasomatised mantle. The resulting mantle upwell ing lead to melting within hydrated mantle wedge material. Although Cadman et al.'shypothesis would explain elevated water contents postulated for Kangâmiut dyke magmas, such an origin would also be expected to impart an arc geochemical signature to the magmas. It is instructive to directly compare the composition of the Kangâmiut dykes with those from the Clear LakeVolcanic Field located in the coastal region of northern California and associated with the development of a slab window after passage of the $M$ endocino Triple Junction (Furlong \& Schwartz 2004). Figure 10 compares the $\mathrm{Ba} / \mathrm{L}$ a and $\mathrm{N} \mathrm{b} / \mathrm{L}$ a ratios for C lear Lake basalts, with typical arc basal ts, the Kangâmiut dykes and continental flood basalts. It is evident from these, among other, geochemical indices that the Kangâmiut dykes lack the expected arc signature postulated by Cadman et al. (2001). Rather the Kangâmiut dykes have compositions consistent with their derivation from asthenospheric mantle supplying normal continental flood basalts.

\section{Active rifting, plume and passive rifting hypotheses}

The temperature of the mantle is an important difference between plumeassociated rifting and passiverifting. $M$ ayborn \& Lesher (2004) presented a detailed analysis of the

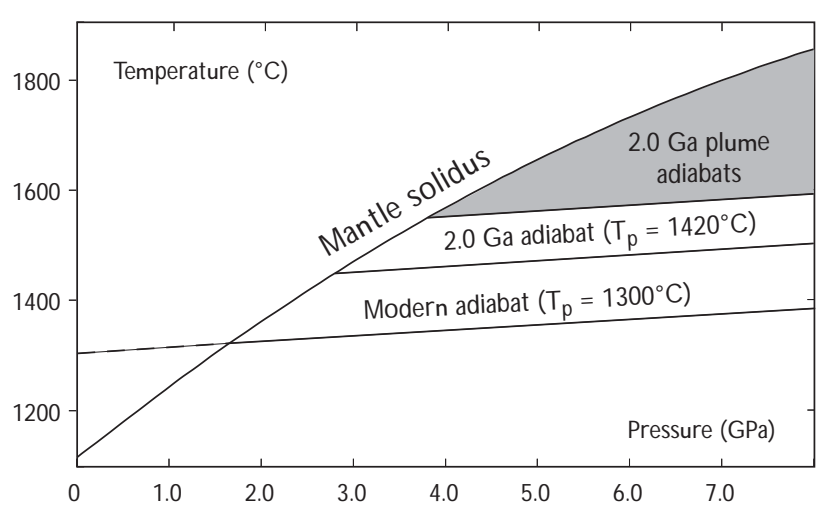

Fig. 12. Plot showing the fertile peridotite solidus and adiabats for modern mantle, $2.0 \mathrm{G}$ a mantle, and plume mantle associated with potential temperatures of 100 to $300^{\circ} \mathrm{C}$ greater than $2.0 \mathrm{G}$ a mantle. Pressures and temperatures for the fertile peridotite from $\mathrm{H}$ irschmann (2000). Slightly modified from M ayborn \& Lesher (2004).

temperature of the mantle during Kangâmiut dyke magma genesis as constrained by REE systematics. They used the algorithm of Fram \& Lesher (1993), as shown in Fig. 11 , to propose that the K angâmiut dykes are the results of mantle melting with a mean solidus pressure of c. 2.75 $\mathrm{GPa}$ and a mean extent of melting of $5 \%$. When compared to the solidus for nominally anhydrous mantle (Fig. 12), this mean solidus temperature would correspond with a potential mantle temperature of $1420^{\circ} \mathrm{C}$. This temperature estimate falls at the lower end of potential temperatures estimated for C. $2.0 \mathrm{G}$ a mantle by Richter (1984, $\left.1420-1600^{\circ} \mathrm{C}\right)$ and Abbott et al. $\left(1994,1380-1680^{\circ} \mathrm{C}\right)$ based on secular cooling models and geochemical data for Precambrian M O RB-type basalts, respectively. Addition-

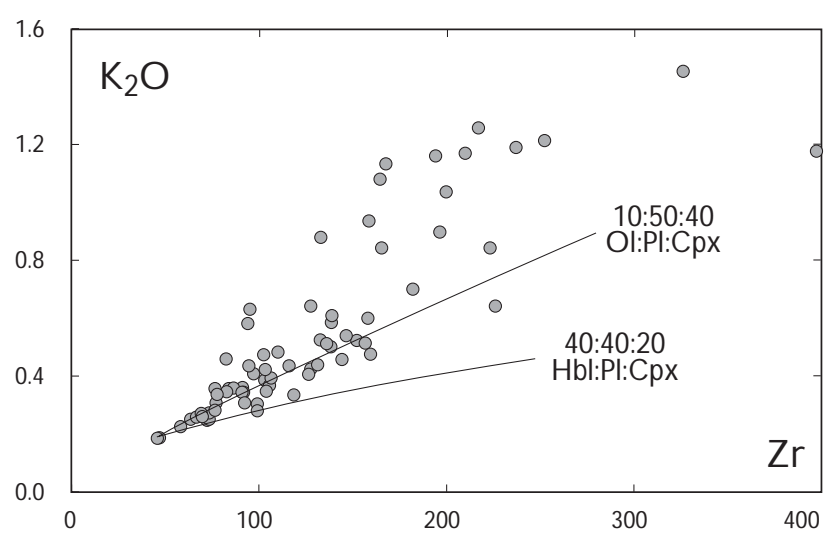

Fig. 13. Variation of $\mathrm{K}_{2} \mathrm{O}$ (in wt\%) with $\mathrm{Zr}$ (in ppm) for the Kangâmiut dykes. Solid lines show results of fractional crystallisation models using mineral proportions of 10:50:40 O I:Pl:C px and 40:40:20 $\mathrm{H}$ bl:Pl:Cpx. The model starting composition is the sample with lowest $\mathrm{K}_{2} \mathrm{O}$ and $\mathrm{Zr}$, which are $0.19 \mathrm{wt} \% \mathrm{~K}_{2} \mathrm{O}$ and $47 \mathrm{ppm} \mathrm{Zr}$. Based on Cadman et al. (2001). 
ally, an ambient mantle potential temperature of $1420^{\circ} \mathrm{C}$ at $2.0 \mathrm{Ga}$. is consistent with constraints from continental freeboard that suggests that mantle temperatures were below $1430^{\circ} \mathrm{C}$ by the mid-Archaean (Galer 1991). T hus, the $1420^{\circ} \mathrm{C}$ mantletemperature for the K angâmiut dykes is consistent with ambient mantle temperatures for that time, reducing the need for anomalously high potential temperatures commonly associated with plume magmatism. The explanation that best fits both the geochemical and field data is that the K angâmiut dykes formed by decompression melting in a rift environment under ambient mantle conditions. This conclusion implies that the dykes are the products of rifting of K enorland supercontinent between 2.1 and $2.0 \mathrm{Ga}$ (Williams et al. 1991). The implications of these findings for the temperature of the Palaeoproterozoic mantle, the occurrence of Palaeoproterozoic mantle plumes, and for Palaeoproterozoic continental crustal growth arediscussed in M ayborn \& Lesher (2004).

\section{Fractionation of the Kangâmiut dykes}

Asnoted previously, therangein $\mathrm{M}$ g-number (0.60-0.21) of the Kangâmiut dykes shows that they are not in equilibrium with mantle peridotite and do not represent direct mantle melts. Thus, even the most primitivesampled Kangâmiut dyke represents an evolved magma. First order observations of the whole-rock and mineral data show that the dykes evolved by OI:Cpx:PI or $\mathrm{H}$ bl:Cpx:PI fractionation with the late-stage introduction of Fe-Ti oxides into the fractionating assemblage. W indley (1970) and Bridgwater et al. (1995) proposed that hornblende was a primary crystallising phasefrom theK angâmiut dykemagmas partly based on the occurrence of large hornblende crystals in chilled margins. H owever, our petrographical studies of the chilled margins show that these amphiboles grew in situ during the final stage of solidification (see Fig. 3). This does not preclude the possibility that hornblende was a stable and fractionating phase at depth and thus influenced the composition of evolved Kangâmiut dyke magmas prior to their emplacement.

Themain difference between $\mathrm{H}$ bl:Cpx:Pl and O I:C px:PI crystallisation to explain the magmatic evolution of the dykes is the relative cotectic proportions of hornblende and olivine. In the projection from QTZ (Fig. 6A) the dyke compositions lie within both the $\mathrm{H} \mathrm{bl:Cpx:PI} \mathrm{and}$ OI:C px:PI phase volumes. If hornblende is a fractionating phase its cotectic proportion would be c. 0.40 (based on the projections from QTZ, CPX, and PLAG), with plagioclase and clinopyroxene at 0.40 and 0.20 , respec- tively. If olivine, and not hornblende, is a fractionating phase, the cotectic proportions would be c. 0.10 olivine, 0.50 plagioclase, and 0.40 clinopyroxene.

These different cotectic proportions can be used to determine if hornblendeor olivine was a fractionating phase by examining the partitioning behaviour of potassium. Experimentally determined amphibole-basaltic melt $\mathrm{K}$ ds for potassium range between 1 and 2 (Green 1994). In contrast, the olivine basaltic melt $K d$ is c. 0.0005 (G reen 1994) for potassium between olivine and basaltic liquid. Figure 13 shows the results of fractional crystallisation modelling for $\mathrm{K}_{2} \mathrm{O}$ and $\mathrm{Zr}$. T he cotectic assemblage 40:40:20 H bl:C px:Pl gives a bulk distribution coefficient (D) of 0.52 for $\mathrm{K}$ and 0.094 for $\mathrm{Zr}$. The olivine-bearing assemblage, 10:50:40 O I:C px:Pl, gives a bulk $D$ of 0.16 for $\mathrm{K}$ and 0.026 for $\mathrm{Zr}$. As shown in Fig. 13, the hornblende-bearing assemblage underestimates the concentration of $\mathrm{K}_{2} \mathrm{O}$ and is not consistent with the trend defined by the dyke data, whereas the olivine-bearing assemblage provides a better fit to the data. Thus, these relationships show that the Kangâmiut dykes evolved by the fractionation of olivine, clinopyroxene, plagioclase and late stage FeTi oxides, and that hornblende was not a significant fractionating phase at any stage of their evolution. Support for this conclusion comes from the $0.8 \mathrm{GPa}$ melting experiments of $M$ ayborn (2000) showing that the cotectic assemblage for a water-bearing $K$ angâmiut dyke starting material is olivine, clinopyroxene, and plagioclase, but no hornblende.

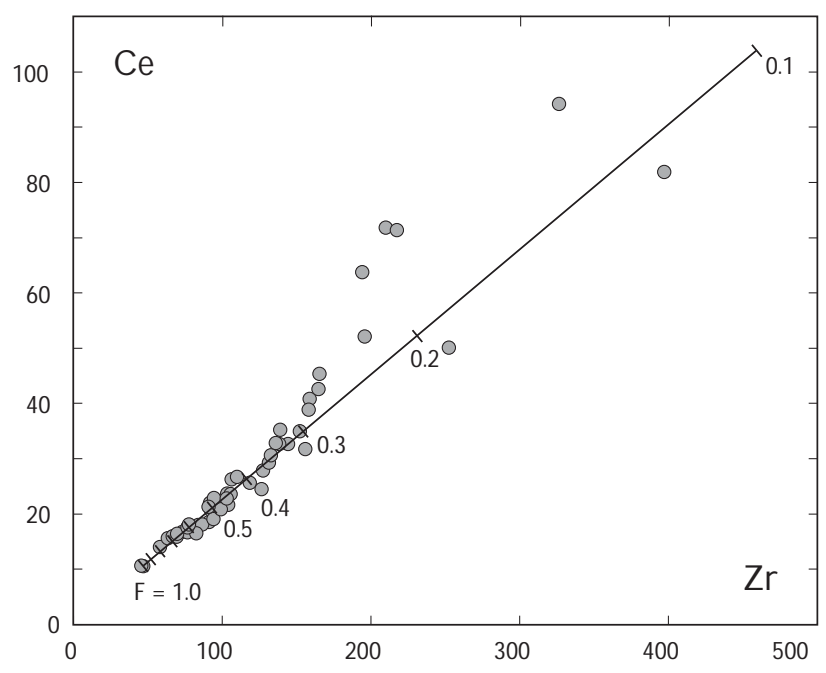

Fig. 14. Variation of $\mathrm{Ce}$ with $\mathrm{Zr}$ (in ppm) showing the results of a fractional crystallisation model where $F$ is the melt proportion. Tic marks on model curve are drawn at 0.1 intervals of $F$. 


\section{0 rigin of water in the Kangâmiut dykes}

Based on the presence of hornblende in the Kangâmiut dykes, Bridgwater et al. (1995) speculated that the parental magmas for the dykes were derived from a hydrous protolith during thrusting of an amphibolite facies terrain beneath the granulite facies terrain in the southern $\mathrm{N}$ agssugtogidian orogen. Although this model does offer an explanation for the proposed high water contents of the dykes, the presence of hornblende itself, often as reaction rims on clinopyroxene or poikilitic grains enclosing plagioclase and clinopyroxene, only argues for elevated water contents during final stages of crystallisation of the dykes. It is, therefore, possible that the high water contents sufficient to stabilise hornblende resulted solely from its enrichment during crystal fractionation.

The modal abundance of hornblende in dykes not affected by Nagssugtogidian deformation is c. $5-20 \%$ for dolerites and $10-35 \%$ for dioritic centres. Since amphiboles contain c. $2 \mathrm{wt} \%$ water, these modes would indicate a whole rock water concentration of $0.1 \mathrm{wt} \%$ in the primitive dolerites and $0.7 \mathrm{wt} \%$ in the more evolved dioritic centres. W hether these differences in concentrations between the primitive and evolved samples are related to enrichment during crystal-liquid fractionation can beevaluated using the following equation for fractional crystallisation:

$$
C_{L}=C_{0} \times F^{(D-1)}
$$

where $\mathrm{C}_{0}$ is the initial concentration, $\mathrm{C}_{L}$ is the liquid concentration, $F$ is the proportion of liquid, and $D$ is the bulk distribution coefficient. Danyuschevsky et al. (2000) showed that in mafic systems water will have a bulk distribution coefficient of c. 0.01 . Starting with a magma with 0.1 wt\% $\left(\mathrm{C}_{0}\right) \mathrm{H}_{2} \mathrm{O}$, representing the primitive dolerites, and ending with 0.7 wt $\%\left(\mathrm{C}_{L}\right) \mathrm{H}_{2} \mathrm{O}$, representing the evolved dioritic centres, requires $86 \%$ crystallisation ( $F=0.14)$ of the primitive magma. Figure 14 shows the relative enrichment of highly incompatible elements $\mathrm{Zr}$ and $C$ e during fractional crystallisation, where $C$ e is used as a proxy for water given their similar incompatibilities (D anyuschevsky et al. 2000). The amount of fractionation required to relate the primitive samples to dioritic centres is $0.3-0.13$, corresponding to $70-87 \%$ crystallisation. Thus, the evolved dykes reflect sufficient fractionation to explain the difference in water concentrations between the primitive dykes and dioritic centres.

The origin of the water in the primitive dykes can al so beaddressed using equation 1. T hemost primitive Kangâmiut dykes ( $\mathrm{M}$ gO > $6 \mathrm{wt} \%$ ) have a modal hornblende content of $5-10 \%$ indicating a maximum of $0.1-0.2$ wt $\%$ water content in the rocks. T his suggests that the amount of water in the parental magma derived from the mantle is less than $0.2 \mathrm{wt} \%$. Equation 1 can also approximate fractional mantle melting and can help constrain the amount of water in the mantle source needed to produce a primitive magma containing $0.2 \mathrm{wt} \% \mathrm{H}_{2} \mathrm{O}$. In this case, the unknown variable is $\mathrm{C}_{0}$, the initial concentration in the mantle. The concentration in the liquid $\left(C_{1}\right)$ is 0.2 wt $\%$, and $D$ is equal to 0.01 . The evaluation of REE systematics, presented by M ayborn \& Lesher (2004) and illustrated in Fig. 11, shows that the average $F$ value for mantle melting leading to the Kangâmiut dykes was 0.05 . Thus, using these values in equation 1 results in a concentration in the mantle source $\left(\mathrm{C}_{0}\right)$ of $0.01 \mathrm{wt} \%$ (100 ppm). T his is well within the range of 28-300 ppm H ${ }_{2} \mathrm{O}$ given by Bell $\&$ Rossman (1992) for the upper mantle containing nominally anhydrous phases. As such, the water present in thehornblende within theK angâmiut dykes can be reasonably accounted for given estimates of its original concentration in primary melts and enrichment through subsequent differentiation. Although these considerations do not rule out Bridgwater et al.'s(1995) model for the Kangâmiut dykes derived from an amphibolite facies protolith, we show that differentiation of partial melts derived from depleted upper mantle can readily explain the occurrence of late crystallising hornblende in the evolved Kangâmiut magmas.

The Kangâmiut dykes and the $\mathrm{N}$ agssugto qidian orogeny

The preservation of both igneous and metamorphic features in the Kangâmiut dyke swarm provides an excellent opportunity to evaluate the amount of crustal thickening that likely occurred during the $\mathrm{N}$ agssugtogidian orogeny. $D$ etermining the amount of thickening requires knowledge of the depths associated with emplacement and peak metamorphism for currently exposed dykes.

Field relationships show brittle deformation of host rocks and segmentation of the Kangâmiut dykes into en échelon arrays during emplacement. Reches \& Fink (1988) proposed that the segmentation of dykes into en échelon arrays occurs when they cross from the ductile into the brittle regime. In modern continental crust the brittleductile transition is observed as the seismic to aseismic transition at depths of 10-15 km (C hen \& M olnar 1983). Chen \& M olnar (1983) and W illiams (1996) give temperatureestimatesfor thebrittle-ductiletransition between 450 and $250^{\circ} \mathrm{C}$. 
Fahrig \& Bridgwater (1976) presented Palaeomagnetic data from dykes and host rocks unaffected by $\mathrm{N}$ agssugtogidian metamorphism, and showed that the host rocks and dykes record different declinations. These differences in declination show that the host rocks were below their Curie temperature during dyke emplacement. Fahrig \& Bridgwater (1976) do not discuss the magnetic carrier in the host rocks, but an examination of host rock samples suggests that the magnetic carrier(s) are magnetite and/or ilmenite. The C urie temperatures of these minerals vary due to solid solutions amongst magnetite-ulvöspinel and hematite-ilmenite, but the upper limit is $580^{\circ} \mathrm{C}$ if the magnetic carrier is pure magnetite.

Additional support for dyke emplacement into host rocks with temperatures below $580^{\circ} \mathrm{C}$ comes from ${ }^{40} \mathrm{Ar} /$ ${ }^{39} \mathrm{Ar}$ dating of dykes and host rocks. Willigers et al. (1999) presented ${ }^{40} \mathrm{Ar} /{ }^{39} \mathrm{Ar}$ cooling ages from dykes in the southern foreland that gave a mean age of $2.02 \mathrm{G}$ a. This age is within error of the $2.04 \mathrm{G}$ a emplacement age determined by dating of igneous zircons (Nutman et al. 1999). The ${ }^{40} \mathrm{Ar} /{ }^{39} \mathrm{Ar}$ cooling age of a regional granitic host rock is 2.5 $\mathrm{Ga}$ (Willigers et al. 1999). This older age indicates that the host rocks have remained below $480^{\circ} \mathrm{C}$, the closure temperature of argon in hornblende ( $\mathrm{H}$ arrison 1981), since $2.5 \mathrm{Ga}$.

Field evidence of brittle deformation, Palaeomagnetic data, and ${ }^{40} \mathrm{Ar} /{ }^{39} \mathrm{Ar}$ cooling ages all indicates that the peak crustal temperatures of exposed basement hosting the K angâmiut dykes were less than c. $450^{\circ} \mathrm{C}$ at the time of dyke emplacement. Estimates of the geothermal gradient appropriate for continental crust at $2.0 \mathrm{G}$ a can help to constrain the depth of the $450^{\circ} \mathrm{C}$ isotherm and thus the depth of dyke emplacement. The geotherm is computed from

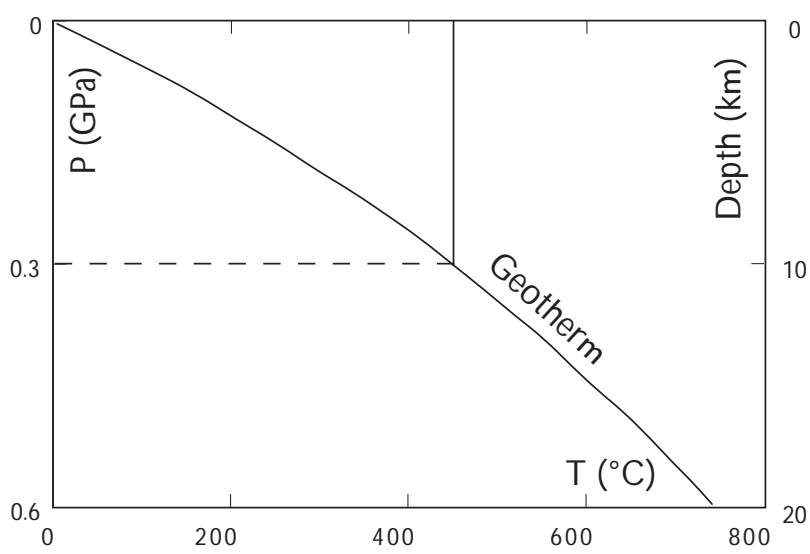

Fig. 15. Model continental geotherm constructed using the heat flow equation shown in text (equation 2). Solid vertical line represents the $450^{\circ} \mathrm{C}$ isotherm that intersects the geotherm at c. $0.3 \mathrm{GPa}(10 \mathrm{~km})$ as shown by dashed horizontal line.

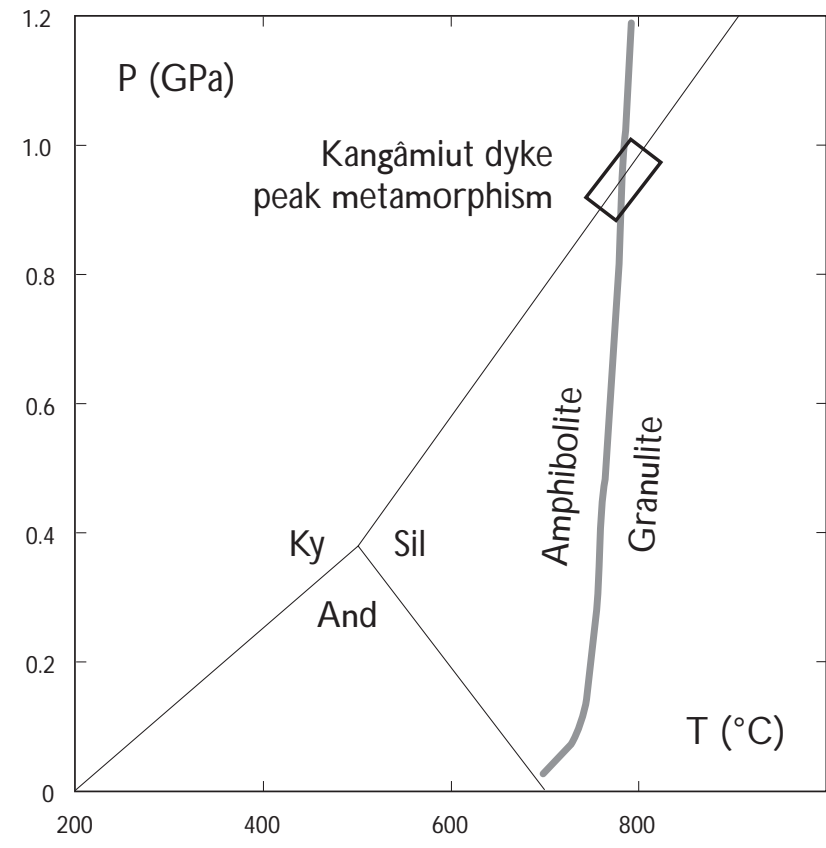

Fig. 16. Pressure versus temperature diagram showing the intersection of the amphibolite/granulite facies transition with the kyanitesillimanite transition. The black rectangle around the intersection shows possible temperatureand pressure ranges of peak metamorphism of the Kangâmiut dykes and metasediments in I kertooq fjord. The $\mathrm{Al}_{2} \mathrm{SiO}_{5}$ phase diagram is from $\mathrm{H}$ oldaway (1971) and the amphibolite to granulite transition is based on the first occurrence of orthopyroxene in experiments on mafic rocks by Spear (1981).

the heat flow equation assuming an exponential distribution of heat producing elements that includes contributions from heat conduction, advection, and production (Carslaw \& Jaeger 1959):

$$
T=\frac{Q^{*} z}{k}+\frac{A^{o} D^{2}}{k}\left(1-e^{-z / H r}\right)
$$

where $\mathbf{T}$ is temperature in ${ }^{\circ} \mathrm{C}, \mathbf{Q} *$ is the reduced heat flow at the crust-mantle boundary in $\mathrm{mW} \mathrm{m}^{-2}, \mathbf{z}$ is the depth in $\mathrm{km}$, $\mathbf{k}$ is the thermal conductivity of the crust in $\mathrm{Wm}^{-1} \mathrm{~K}^{-}$ ${ }^{1}, \mathbf{A}^{0}$ is the concentration of heat producing elements at the earth's surface in $\mu \mathrm{Wm}^{-3}$, D is crustal thickness in $\mathrm{km}_{\text {, }}$ and $\mathbf{H} \mathbf{r}$ is the length scale for the decrease in heat producing elements with depth in $\mathrm{km}$. Current average values are $\mathrm{Q}=30 \mathrm{mWm}^{-2}, \mathrm{k}=2.25 \mathrm{Wm}^{-1} \mathrm{~K}^{-1}, \mathrm{~A}^{0}=0.75 \mu \mathrm{Wm}$ ${ }^{3}, \mathrm{D}=35 \mathrm{~km}$, and $\mathrm{Hr}=15 \mathrm{~km}$. The model geotherm shown in Fig. 15 uses these values with the exception of $A^{0}=1.2$ to account for higher heat production during the Palaeoproterozoic and Archaean (Stein 1995). U sing the geotherm in Fig. 15 and a maximum host rock tempera- 
ture of $450^{\circ} \mathrm{C}$ require that the dykes intruded to a minimum depth of $10 \mathrm{~km}$ corresponding to a lithostatic pressure of c. $0.3 \mathrm{GPa}$. This estimate of a shallow emplace ment level for the dykes is also supported by the clustering of wholerock data near the low-pressure $0 \mathrm{I}: \mathrm{Cpx}: \mathrm{PI}$ cotectics as previously shown in Fig. 7.

Application of the clinopyroxene geothermobarometry developed by Putirka et al. (1996) provides another independent estimate of the depth of dyke emplacement. This geothermobarometer uses compositions of clinopyroxenes and their host rocks to estimate the pressure and temperature of clinopyroxene crystallisation. Therearetwo important assumptions when applying this geothermobarometer to chilled margins in the Kangâmiut dykes. First, we assume that the whole rock composition is a close approximation of theoriginal liquid composition. Second, we assume that the cores of the clinopyroxene phenocrysts were once in equilibrium with this liquid. 0 ne test of equilibrium between thewhole-rock and clinopyroxene phenocrysts is given by the $\mathrm{Fe} / \mathrm{M} g \mathrm{O}$ ratios in the whole rocksand pyroxenes. The $\mathrm{FeO} / \mathrm{M}$ gO ratios in theclinopyroxenes from eight chilled margins and the $\mathrm{FeO} / \mathrm{M} \mathrm{gO}$ ratio in their host rocksyield an average $K_{D}$ FeMg for clinopyroxeneand liquid of $0.32 \pm 4$. Based on experimental work, $\mathrm{K}_{\mathrm{D}}{ }_{\mathrm{FeMg}}$ for basaltic systems between $1 \mathrm{~atm}$ and $1.5 \mathrm{GPa}$ ranges from 0.22-0.36 (Baker \& Eggler 1987; Putirka et al. 1996). O ur estimates for the Kangâmiut dykes fall within this range.

A pplyingthePutirkaet al. (1996) geothermobarometer to clinopyroxene phenocrysts cores and whole rock compositions from chilled margins of eight K angâmiut dykes gives temperatures of $1199-1170^{\circ} \mathrm{C}$ and pressures of $0.75-$ $0.35 \mathrm{G} \mathrm{Pa}$. The upper pressure limit of $0.75 \mathrm{G} \mathrm{Pa}$ indicates a maximum recorded depth of fractionation recorded by clinopyroxene phenocrysts of c. $25 \mathrm{~km}$. The lower pressure estimate of $0.35 \mathrm{GPa}$ constrains a maximum emplace ment depth of c. $12 \mathrm{~km}$, since the clinopyroxene phenocrysts in the chilled margins must have formed at a depth greater or equal to the final depth of dyke emplacement. Thisis consistent with the preceding results from temperatureestimates of thehost rocksduring emplacement that indicate a maximum of c. $0.3 \mathrm{G} \mathrm{Pa}$ or a depth of c. $10 \mathrm{~km}$.

If these independent estimates of the Kangâmiut dyke emplacement depths are taken as representative of the dyke swarm in general, then a consideration of peak metamorphic conditions during the $\mathrm{N}$ agssugtoqidian orogeny can be used to constrain the amount of crustal thickening during orogenesis. The majority of the metamorphism of the northern portion of the swarm during the N agssugtoqidian orogeny occurred at amphibolite facies, with the exception of the northernmost portion within Ikertooq fjord where the transition to granulite facies metamorphism occurs. The amphibolite to granulite facies transition is marked by the first appearance of orthopyroxene in mafic rocks and is known to occur at c. $800^{\circ} \mathrm{C}$ (Spear 1981). The constraint on the pressure of thegranulite facies metamorphism comes from the presence of kyanite-sillimanite paragneisses that are interleaved with sheets of dyke-bearing orthogneisses. The presence of granulite facies metamorphosed Kangâmiut dykes and the alumina-silicate-bearing gneisses indicates that peak metamorphism occurred at conditions corresponding to both the amphibolite to granulite and kyanite to sillimanite transitions. Figure 16 shows that these transitions indicate a peak metamorphic pressure of c. $0.9 \mathrm{GPa}$. This pressure is consistent with the results of $\mathrm{M}$ engel et al. (1995) who determined metamorphic pressures on the Kangâmiut dykes in the I kertooq region using T W EEQ U geothermobarometry (Berman 1991).

Knowing the approximate depth of emplacement and the pressure of peak metamorphism provides constraints on the amount and style of burial during the $\mathrm{N}$ agssugtoqidian orogeny. Emplacement at $0.3 \mathrm{GPa}$ of pressure followed by peak metamorphism at $0.9 \mathrm{G}$ Pa requires an increase of $0.6 \mathrm{G} \mathrm{Pa}$. This indicates a minimum of $20 \mathrm{~km}$ of crustal thickening between dyke emplacement and peak metamorphism. A probable mechanism of crustal thickening in this case is thrust imbrication and crustal loading of material from north to south. The structural feature associated with this imbrication is most likely the I kertôq shear zone (Fig. 1). The imbrication of rock types, the lithostratigraphic changes, including the disappearance of the K angâmiut dykes, and the lateral continuity of the I kertôq shear zone suggest that it is a major structure capable of accommodating displacement of material that buried the northern portion of the dyke swarm with $20 \mathrm{~km}$ of overburden. Crustal thickening must have occurred over a minimum map distance of $50 \mathrm{~km}$ extending from the Ikertôq shear zone to at least the Itivdleq shear zone (Fig. 1) and farther to the south approaching the $\mathrm{N}$ agssugtogidian front where the last significant metamorphism occurs.

\section{Summary and conclusions}

The 2.04 Ga Kangâmiut dyke swarm in West Greenland is composed of tholeiitic dykes that intruded during passive rifting of Archaean continental crust. T hecurrent level of exposure corresponds to emplacement depths less than $10 \mathrm{~km}$ based on estimated host rock temperatures less than $450^{\circ} \mathrm{C}$ during emplacement and geothermobarometry for 
Kangâmiut dyke clinopyroxenes. M ajor and trace element systematics show that the parental magmas for the Kangâmiut dykes differentiated by fractionation of plagioclase, clinopyroxene, olivine, and late state Fe-Ti oxides. The rare-earth element systematics of the dykes indicate initiation of mantle melting at c. $2.75 \mathrm{GPa}$, corresponding to a potential mantle temperature of $\mathrm{C} .1420^{\circ} \mathrm{C}$. T his temperature is consistent with ambient mantle temperature estimates for $2.0 \mathrm{G}$ a and shows that the Kangâmiut dyke swarm formed during passive rifting of the Kenorland supercontinent. Anomalously hot plume mantle is not required for their generation. Subsequent metamorphism of thenorthern portion of the swarm reached granulite facies, with an estimated temperature of $800^{\circ} \mathrm{C}$ and pressure of $0.9 \mathrm{GPa}$. The emplacement pressure of less than $0.3 \mathrm{GPa}$ and peak metamorphism at $0.9 \mathrm{GPa}$ indicate a minimum of $20 \mathrm{~km}$ of crustal thickening associated with the N agssugtogidian orogeny. C rustal thickening likely occurred during thrusting of material from thecentral N agssugtogidian orogen southward over the southern $\mathrm{N}$ agssugtoqidian orogen along the I kertôq shear zone.

\section{Acknowledgements}

We are especially grateful to the late D avid Bridgwater, whose boundless energy and enthusiasm for the Kangâmiut dykes inspired this work from beginning to end. We also thank Flemming M engel, Jim Connelly, and M inik Rosing for their support of this project at various stages, and Andy Saunders and Karen $\mathrm{H}$ anghøj for their constructive reviews of the final manuscript. This work was partially supported by the D anish Lithosphere C entreand grants from the US National Science Foundation (EAR 97-06677 and O CE 98-11453).

\section{References}

Abbott, D ., Burgess, L., Longhi, J. \& Smith, W.H .F. 1994: An empirical thermal history of the Earth's upper mantle. Journal of Geophysical Research 99(7), 13835-13850.

Arculus, R.J . 1994: Aspects of magma genesis in arcs. Lithos 33(1-3), 189-208.

Aspler, L.B. \& Chiarenzelli, J.R. 1998: Two N eoarchean supercontinents? Evidence from the Paleoproterozoic. Sedimentary Geology 120(1-4), 75-104.

Bacon, C.R., Bruggman, P.E., Christiansen, R.L., Clynne, M .A., D onnelly-N olan, J.M . \& H ildreth, W. 1997: Primitive magmas at five C ascadevolcanic fields; meltsfrom hot, heterogeneoussub-arc mantle. Canadian M ineralogist 35(4), 397-423.

Bailey, J.C., Frolova, T.I \& Burikova, I.A. 1989: M ineralogy, geochem- istry and petrogenesis of Kurileisland-arc basalts. C ontributions to M ineralogy and Petrology 102(3), 265-280.

Bak, J., Korstgård, J. \& Sørensen, K. 1975: A major shear zone within the N agssugtogidian of West Greenland. Tectonophysics 27(3), 191209.

Baker, D.R. \& Eggler, D.H. 1987: Compositions of anhydrous and hydrous melts coexisting with plagioclase, augite, and olivine or lowCa pyroxene from $1 \mathrm{~atm}$ to $8 \mathrm{kbar}$; application to the Aleutian volcanic center of Atka. American M ineralogist 72(1-2), 12-28.

Baker, M.B. \& Stolper, E.M . 1994: D etermining the composition of high-pressure mantle melts using diamond aggregates. Geochimica et Cosmochimica Acta 58(13), 2811-2827.

Becker, H ., Jochum, K.P. \& Carlson, R.W. 1999: Constraintsfrom highpressure veins in eclogites on the composition of hydrous fluids in subduction zones. Chemical G eology 160(4), 291-308.

Bell, D .R . \& Rossman, G.R. 1992: Water in Earth's mantle; the role of nominally anhydrous minerals. Science 255(5050), 1391-1397.

Berman, R.G. 1991:T hermobarometry using multi-equilibrium calculations; a new technique, with petrological applications. The C anadian M ineralogist 29, 833-855.

Blichert-Toft, J., Rosing, M .T., Lesher, C.E. \& Chauvel, C. 1995: Geochemical constraints on the origin of the late Archean Skjoldungen alkalineigneousprovince, SE G reenland. Journal of Petrology 36(2), 515-561.

Bridgwater, D ., M engel, F., Fryer, B., Wagner, P. \& H ansen, S.C. 1995 Early Proterozoic mafic dykes in the $\mathrm{N}$ orth Atlantic and Baltic Cratons: field setting and chemistry of distinctive swarms. In: C oward, M.P. \& Ries, A.C. (eds): Early Precambrian processes. Geological Society Special Publication (London) 95, 193-220.

Brophy, J.G. \& M arsh, B.D . 1986: On the origin of high alumina arc basalt and the mechanics of melt extraction. Journal of Petrology 27(4), 763-789.

Cadman, A.C., N oble, S.R., Tarney, J., Park, G., Ryan, A.B. \& Royse, K.R. 1999: U-Pb ages of syndeformational dykes associated with the M esoproterozoic $N$ ain Plutonic Suite, Labrador. C anadian Journal of Earth Sciences 36(3), 339-348.

Cadman, A.C., Tarney, J., Bridgwater, D ., M engel, F.C., Whitehouse, M.J. \& Windley, B.F. 2001: The petrogenesis of the Kangâmiut dyke swarm, W. G reenland. Precambrian Research 105, 183-203.

Carslaw, H.S. \& Jaeger, J.C. 1959: Conduction of heat in solids, 510 pp., 0 xford: Clarendon Press.

Chen, W. \& M olnar, P. 1983: Focal depths of intracontinental and intraplate earthquakes and their implications for the thermal and mechanical properties of the lithosphere. Journal of $\mathrm{G}$ eophysical Research 88(5), 4183-4214.

Connelly, J.N \& \& Mengel, F.C. 2000: Evolution of Archean components in the Paleoproterozoic N agssugtogidian orogen, West $\mathrm{G}$ reenland. Geological Society of America Bulletin 112(5), 747-763.

Connelly, J.N ., van Gool, J.A.M . \& M engel, F.C . 2000: Temporal evolution of a deeply eroded orogen: the $N$ agssugtogidian O rogen, West Greenland. Canadian J ournal of Earth Sciences37, 1121-1142.

D anyuschevsky, L.V., Eggins, S.M ., Falloon, T.J . \& Christie, D .M . 2000: $\mathrm{H}_{2} \mathrm{O}$ abundancein depleted to moderately enriched mid-ocean ridge magmas; Part 1: Incompatiblebehavior, implicationsfor mantlestor- 
age, and origin of regional variations. Journal of Petrology 41, 1329 1364.

Escher, A. \& Pulvertaft, T.C.R. 1976: Rinkian mobilebelt of West G reenland. In: Escher A. and W att W.S. (eds): Geology of G reenland, 104-119. Copenhagen: Geological Survey of G reenland.

Escher, A., Escher, J.C. \& Watterson, J. 1975: The reorientation of the Kangâmiut dike swarm, West Greenland. C anadian Journal of Earth Sciences 12, 158-173.

Escher, A., Jack, S. \& Watterson, J. 1976: T ectonics of the North Atlantic Proterozoic dyke swarm. Philosophical Transactions of the R oyal Society of London, Series A: M athematical and Physical Sciences 280(1298), 529-539.

Fahrig, W.F. \& Bridgwater, D. 1976: Late Archean - early Proterozoic paleomagnetic pole positions from West G reenland. In: W indley, B.F. (ed.): Early history of the Earth, 427-439. New York: John W iley $\&$ Sons.

Fram, M.S. \& Lesher, C.E. 1993: Geochemical constraints on mantle melting during creation of the $\mathrm{N}$ orth Atlantic basin. N ature 363 , 712-715.

Francalanci, L., Taylor, S.R., M cC ulloch, M .T. \& Woodhead, J.D . 1993: $\mathrm{Geochemical}$ and isotopic variations in the calc-alkaline rocks of Aeolian arc, southern Tyrrhenian Sea, Italy; constraints on magma genesis. Contributions to $M$ ineralogy and Petrology 113(3), 300313.

Friend, C.R.L. \& N utman, A.P. 1994: Two Archaean granulite-facies metamorphic eventsin the $N$ uuk- $M$ aniitsog region, southern West $G$ reenland; correlation with the Saglek Block, Labrador. Journal of the Geological Society (London) 151, 421-424.

Furlong, K.P. \& Schwartz, S.Y. 2004: Influence of the M endocino triple junction on the tectonics of coastal California. Annual Review of Earth and Planetary Sciences 32, 403-433.

Galer, S.J.G. 1991: Interrelationships between continental freeboard, tectonics and mantletemperature. Earth and Planetary Science Letters 105(1-3), 214-228.

Green, T.H . 1994: Experimental studies of trace-ement partitioning applicable to igneous petrogenesis; Sedona 16 years later. Chemical G eology 117(1-4), 1-36.

Gribble, R.F., Stern, R.J., N ewman, S., Bloomer, S.H . \& O 'H earn, T. 1998: Chemical and isotopic composition of lavas from the northern $\mathrm{M}$ ariana Trough; implications for magmagenesis in back-arc basins. Journal of Petrology 39(1), 125-154.

Grocott, J. 1979: Shape fabrics and superimposed simple shear strain in a Precambrian shear belt, West G reenland. Journal of the $G$ eological Society (London) 136(7), 471-489.

Gust, D .A., Arculus, R.J . \& Kersting, A.B. 1997: Aspects of magma sources and processes in the Honshu Arc. Canadian M ineralogist 35(4), 347-365.

H ageskov, B. 1995: Structural evolution of the southern Nagssugtogidian front and the role of the Kangâmiut dykes. Terra N ova $\mathbf{7}$, 107 only.

H anmer, S., M engel, F., Connelly, J. \& van G ool, J. 1997: Significance of crustal-scale shear zones and synkinematic mafic dykes in the $\mathrm{N}$ agssugtogidian 0 rogen, SW Greenland; a re-examination. Journal of Structural G eology 19(1), 59-75.
$\mathrm{H}$ arrison, T.M . 1981: D iffusion of ${ }^{40} \mathrm{Ar}$ in hornblende. Contributions to $M$ ineralogy and Petrology 78(3), 324-331.

H irschmann, M .M . 2000: M antlesolidus: experimental constraints and the effects of peridotitecomposition. Geochemistry, Geophysics, $\mathrm{Ge}$ osystems 1(10) (http://dx.doi.org/10.1029/2000G C000070).

H oldaway, M .J. 1971: Stability of andal usiteand theal uminum silicate phase diagram. American Journal of Science 271(2), 97-131.

H ooper, P.R. \& Hawkesworth, C.J. 1993: Isotopic and geochemical constraints on the origin and evolution of the Columbia River Basalt. Journal of Petrology 34(6), 1203-1246.

Jakes, P. \& G ill, J. 1970: Rare earth elements and the island arc tholeiitic series. Earth and Planetary Science Letters 9(1), 17-28.

Jenner, G.A., Longerich, H .P., Jackson, S.E. \& Fryer, B.J. 1990: ICPM S; a powerful tool for high-precision trace-element anal ysis in earth sciences; evidence from analysis of sel ected U .S.G .S. reference samples. Chemical Geology 83(1-2), 133-148.

Kalsbeek, F. \& M anatschal, G. 1999: G eochemistry and tectonic significance of peridotitic and metakomatiitic rocks from the Ussuit area, Nagssugtoqidian 0 rogen, West Greenland. Precambrian Research 94, 101-120.

Kalsbeek, F. \& N utman, A.P. 1996: Anatomy of the early Proterozoic $\mathrm{N}$ agssugtogidian $\mathrm{O}$ rogen, West Greenland, explored by reconnaissance SH RI M P U -Pb zircon dating. G eology 24(6), 515-518.

Kalsbeek, F., Pidgeon, R.T. \& Taylor, P.N . 1987: Nagssugtoqidian mobile belt of West Greenland; a cryptic $1850 \mathrm{M}$ a suture between two Archaean continents; chemical and isotopic evidence. Earth and Planetary Science Letters 85(4), 365-385.

Kelemen, P.B., H anghøj, K.\& Greene, A.R. 2003: O ne view of the geochemistry of subduction-related magmatic arcs, with an emphasis on primitive andesite and lower crust. In: Rudnick, R.L., H olland, H.D .\& Turekian, K.K. (eds): Treatise on G eochemistry: the Crust 3, 593-659.

K orstgård, J.A. 1979: M etamorphism of the Kangâmiut dykes and the metamorphic and structural evolution of the southern Nagssugtoqidian boundary in the Itvidleq-Ikertôq region, W est Greenland. Rapport G rønlands G eologiske Undersøgelse 89, 63-75.

K ystol, J. \& Larsen, L.M . 1999: Analytical procedures in the Rock Geochemical Laboratory of the Geological Survey of D enmark and G reenland. G eology of Greenland Survey Bulletin 184, 59-62.

Langmuir, C.H ., K lein, E.M . \& Plank, T. 1992: Petrological systematics of mid-ocean ridge basalts: constraints on melt generation beneath ocean ridges. In: M organ, J.P., Blackman, D.K. \& Sinton, J.M. (eds): $M$ antle flow and melt generation at mid-ocean ridges. Geophysical M onograph 71, 183-280. Washington D.C.: American Geophysical Union.

LeM aitre, R.W. 2002: A classification of igneous rocks and glossary of terms, 2nd edition., 236 pp. Cambridge: CambridgeU niversity Press.

Leake, B.E. et al. 1997: Nomenclature of amphiboles; report of the Subcommittee on Amphiboles of the International M ineralogical Association, Commission on New M inerals and $\mathrm{M}$ ineral Names. American M ineralogist 82(9-10), 1019-1037.

Lightfoot, P.C., H awkesworth, C.J., H ergt, J., N aldrett, A.J ., G orbachev, N.S., Fedorenko, V.A. \& D oherty, W. 1993: Remobilisation of the continental lithosphere by a mantle plume; major-, trace-element, and $\mathrm{Sr}-, \mathrm{N} \mathrm{d}$-, and $\mathrm{Pb}$-isotope evidence from picritic and tholeiitic 
lavas of the N oril'sk D istrict, Siberian Trap, Russia. Contributions to M ineralogy and Petrology 114(2), 171-188.

M anatschal, G., Ulfbeck, D . \& van G ool, J. 1998: C hange from thrusting to syncollisional extension at a mid-crustal level; an example from the Pal aeoproterozoic $N$ agssugtogidian 0 rogen, West $\mathrm{G}$ reenland. Canadian J ournal of Earth Sciences 35(7), 802-819.

M ayborn, K.R. 2000: Petrogenesis of the Paleoproterozoic Kangâmiut dike swarm, W est G reenland: implications for the tectonic history of northeast Laurentia and the evolution of basaltic magmas, 318 pp. Unpublished Ph.D . thesis, University of C alifornia-D avis, USA.

Mayborn, K.R. \& Lesher, C.E. 2004: Paleoproterozoic mafic dike swarms of northeast Laurentia: products of plumes or ambient mantle? Earth and Planetary Science Letters 225(3), 305-317.

M engel, F., van Gool, J. \& M arker, M . 1995: M afic dykes as monitors of orogenic development: an example from the southern margin of the Palaeoproterozoic $N$ agssugtogidian 0 rogen, W est Greenland. Proceedings, First D LC W orkshop on the N agssugtogidian 0 rogen in West Greenland, 6-7 A pril, 15-18. Copenhagen, Denmark: $D$ anish Lithosphere Centre.

M engel, F., B ridgwater, D. \& H ageskov, B. 1996: Southern N agssugtoqidian foreland: tectonic and thermal evolution monitored by the Proterozoic Kangâmiut dyke swarm. LITH O PRO BE Report 57, 177-191.

Miller, D.M., Goldstein, S.L. \& Langmuir, C.H. 1994: Cerium/lead and lead isotope ratios in arc magmas and the enrichment of lead in the continents. N ature 368(6471), 514-520.

N oe-N ygaard, A. 1952: A new orogenic epoch in the pre-Cambrian of Greenland. International G eological Congress, Part 13(59), 199204. International G eological Congress.

Nutman, A.P. \& Bridgwater, D. 1986: Early Archaean Amitsop tonalites and granites of the I sukasia area, southern W est Greenland; development of the oldest-known sial. Contributions to M ineralogy and Petrology 94(2), 137-148.

Nutman, A.P. \& Collerson, K.D. 1991: Very early Archean crustalaccretion complexes preserved in the $\mathrm{N}$ orth Atlantic $\mathrm{Craton}$. $\mathrm{G}$ eology 19(8), 791-794.

Nutman, A.P., Kalsbeek, F., M arker, M ., van G ool, J. \& Bridgwater, D. 1999: U-Pb zircon ages of Kangâmiut dykes and detrital zircons in metasediments in the Palaeoproterozoic Nagssugtogidian 0 rogen (West $\mathrm{G}$ reenland); clues to the precollisional history of the orogen. Precambrian Research 93(1), 87-104.

Papike, J.J., Cameron, K.L. \& Baldwin, K. 1974: Amphiboles and pyroxenes; characterization of other than quadrilateral components and estimates of ferric iron from microprobe data. Abstracts with Programs- Geological Society of America 6, 1053-1054.

Pearce, J.A., Baker, P.E., H arvey, P.K. \& Luff, I.W. 1995: Geochemical evidence for subduction fluxes, mantle melting and fractional crystallization beneath the South Sandwich island arc. Journal of Petrology 36(4), 1073-1109.

Peate, D.W. \& H awkesworth, C.J. 1996: Lithospheric to asthenospheric transition in low-Ti flood basalts from southern Parana, Brazil. Chemical Geology 127, 1-24.

Peffit, M .R., Gust, D.A., Bence, A.E., Arculus, R.J. \& Taylor, S.R. 1980: Chemical characteristics of island-arc basalts; implications for mantle sources. Chemical Geology 30(3), 227-256.
Plank, T. \& Langmuir, C.H . 1988: An evaluation of the global variations in the major element chemistry of arc basalts. Earth and Planetary Science Letters $\mathbf{9 0}(4), 349-370$.

Plank, T. \& Langmuir, C.H . 1992: Effects of themelting regimeon the composition of the oceanic crust. Journal of G eophysical Research 97(13), 19749-19770.

Putirka, K., Kinzler, R., Longhi, R. \& Walker, D. 1996: Thermobarometry of mafic igneous rocks based on clinopyroxene-liquid equilibria, 0-30 kbar. Contributionsto Mineralogy and Petrology 123(1), 92-108.

Ramberg, H . 1949: On the petrogenesis of the gneiss complexes between Sukkertoppen and Christianshaab, West-Greenland. M eddelelser fra Dansk G eologisk Forening 11, 312-327.

Reay, A. \& H arris, B. 1964: The partial fusion of peridotite. Bulletin of Volcanology 27, 115-127.

Reches, Z. \& Fink, J. 1988: The mechanism of intrusion of the Inyo Dike, Long Valley Caldera, California. Journal of $\mathrm{G}$ eophysical Re search 93(5), 4321-4334.

Richter, F.M . 1984: Regionalized models for the thermal evolution of the Earth. Earth and Planetary Science Letters 68(3), 471-484.

Roeder, P.L. \& Emslie, R.F. 1970: Olivineliquid equilibrium. Contributions to M ineralogy and Petrology 29(4), 276-289.

Spear, F.S. 1981: An experimental study of hornblende stability and compositional variability in amphibole. American Journal of Science 281(6), 697-734.

Stein, C.A. 1995: H eat flow of the Earth. In: Ahrens, T.J. (ed.): G lobal earth physics: a handbook of physical constants, 144-158. Washington D.C.: American G eophysical Union.

Stern, R.A., Percival, J.A. \& M ortensen, J.K. 1994: Geochemical evolution of the M into Block; a $2.7 \mathrm{G}$ a continental magmatic arc built on theSuperior proto-craton. Precambrian Research 65(1-4), 115153.

Storey, M., M ahoney, J.J. \& Saunders, A.D. 1997: C retaceous basalts in M adagascar and the transition between plume and continental lithosphere mantle sources. In: M ahoney, J.J. \& C offin, M.F. (eds): Large igneous provinces; continental, oceanic, and planetary flood volcanism, 95-122. Washington D.C.: American G eophysical Union.

Sun, S.S. \& M CD onough, W.F. 1989: Chemical and isotopic systematics of oceanic basalts; implications for mantlecomposition and processes. In: Saunders, A.D. \& N orry, M. J. (eds): M agmatism in the ocean basins. G eological Society Special Publication (London) 42, 313-345.

Takahashi, E. 1986: M elting of a dry peridotite KLB-1 up to 14 G Pa; implications on the origin of peridotitic upper mantle. Journal of Geophysical Research 91(9), 9367-9382.

Tatsumi, Y. 1989: M igration of fluid phases and genesis of basalt magmas in subduction zones. Journal of G eophysical R esearch 94(4), 4697-4707.

Tatsumi, Y., O tofuji, Y., M atsuda, T. \& N ohda, S. 1989: 0 pening of the Sea of J apan back-arc basin by asthenospheric injection. Tectonophysics 166(4), 317-329.

Thompson, R.N. 1982: M agmatism of the British Tertiary volcanic province. Scottish Journal of G eology 18, 49-107.

Tormey, D.R., Grove, T.L. \& Bryan, W.B. 1987: Experimental petrol- 
ogy of normal M ORB near the Kane fracture zone; 22 degree- 25 degree N, M id-Atlantic Ridge. Contributions to Mineralogy and Petrology 96(2), 121-139.

Tormey, D .R., H ickey-Vargas, R., Frey, R.A. \& Lopez-Escobar, L. 1991: Recent lavas from the Andean volcanic front (33-42 degrees $S$ ); interpretations of along-arc compositional variations. In: $\mathrm{H}$ armon, R.S. (ed.): Andean magmatism and its tectonic setting. G eological Society of America Special Paper 265, 57-77.

van G ool, J.A.M ., Kriegsman, L.M ., M arker, M . \& N ichols, G .T. 1999: Thrust stacking in the inner N ordre Strømfjord area, West G reenland; significance for thetectonic evolution of the Palaeoproterozoic $\mathrm{N}$ agssugtoqidian O rogen. Precambrian Research 93(1), 71-85.

van Gool, J.A.M ., Connelly, J.N ., M arker, M . \& M engel, F.C. 2002: The $N$ agssugtogidian O rogen of West $G$ reenland: tectonic evolution and regional correlations from a West Greenland perspective. Canadian Journal of Earth Sciences 39(5), 665-686.

Williams, C.F. 1996: Temperature and the seismic/aseismic transition; observations from the 1992 Landers earthquake. Geophysical Re search Letters 23(16), 2029-2032.
W illiams, H ., H offman, P.F., Lewry, J.F., M onger, J.W.H . \& Rivers, T. 1991: Anatomy of North America; thematic geologic portrayal s of the continent. Tectonophysics 187(1-3), 117-134.

W illigers, B.J.A., M engel, F.C., Bridgwater, D., Wijbrans, J.R. \& van Gool, J.A.M . 1999: M afic dike swarms as absolute time markers in high-grade terranes; ${ }^{40} \mathrm{Ar} /{ }^{39} \mathrm{Ar}$ geochronological constraints on the Kangâmiut dikes, West Greenland. Geology 27(9), 775-778.

W indley, B.F. 1970: Primary quartz ferro-dolerite/garnet amphibolite dykes in the Sukkertoppen region of West Greenland. In: N ewall, G. \& Rast, N. (eds): M echanism of igneous intrusion, 79-92. Liverpool: Seel H ouse Press.

W ooden, J.L., C zamanske, G.K ., Fedorenko, V.A., Arndt, N .T., C hauvel, C., Bouse, R.M ., King, B.W., Knight, R.J . \& Siems, D .F. 1993: I sotopic and trace-element constraints on mantle and crustal contributions to Siberian continental flood basalts, N oril'sk area, Siberia. Geochimica et Cosmochimica Acta 57(15), 3677-3704. 


\section{Appendix}

Table A 1. Field data for Kangâmiut dykes examined for this study

\begin{tabular}{|c|c|c|c|c|c|c|}
\hline Dyke & Location & Latitude & Longitude & Trend & Thickness (m) & Samples \\
\hline 1 & Søndre Strømfjord & $66^{\circ} 05.266^{\prime} \mathrm{N}$ & $053^{\circ} 33.211^{\prime} \mathrm{W}$ & 010 & 2 & $\begin{array}{l}430901 \text { middle of dyke, } \\
430902 \text { near contact }\end{array}$ \\
\hline 2 & Søndre Strømfjord & $66^{\circ} 05.26^{\prime} \mathrm{N}$ & $053^{\circ} 33.5^{\prime} \mathrm{W}$ & 080 & 20 & $430903 \sim 7 \mathrm{~m}$ from dyke contact \\
\hline 3 & Søndre Strømfjord & $66^{\circ} 05.26^{\prime} \mathrm{N}$ & $053^{\circ} 33.5^{\prime} \mathrm{W}$ & 010 & 0.4 & none \\
\hline 4 & Søndre Strømfjord & $66^{\circ} 05.26^{\prime} \mathrm{N}$ & $053^{\circ} 33.7^{\prime} \mathrm{W}$ & 020 & $?$ & none \\
\hline 5 & Itilleq & $66^{\circ} 33.3^{\prime} \mathrm{N}$ & $053^{\circ} 02.5^{\prime} \mathrm{W}$ & 086 & 6 & $430904 \sim 2 \mathrm{~m}$ from contact \\
\hline 6 & Itilleq & $66^{\circ} 33.3^{\prime} \mathrm{N}$ & $053^{\circ} 02.5^{\prime} \mathrm{W}$ & $?$ & 1.5 & 430905 middle of dyke \\
\hline 7 & Ikertooq & $66^{\circ} 58.1^{\prime} \mathrm{N}$ & $052^{\circ} 28.9^{\prime} \mathrm{W}$ & 079 & 0.3 & none \\
\hline 8 & Ikertooq & $66^{\circ} 58.1^{\prime} \mathrm{N}$ & $052^{\circ} 28.9^{\prime} \mathrm{W}$ & 123 & 0.15 & none \\
\hline 9 & Ikertooq & $66^{\circ} 57.55^{\prime} \mathrm{N}$ & $052^{\circ} 31.7^{\prime} \mathrm{W}$ & 010 & 2 & $4309100.5 \mathrm{~m}$ from dyke margin \\
\hline 10 & Ikertooq & $66^{\circ} 58.95^{\prime} \mathrm{N}$ & $052^{\circ} 26.8^{\prime} \mathrm{W}$ & 080 & 2 & 430915 middle of dyke \\
\hline 11 & Ikertooq & $66^{\circ} 49.7^{\prime} \mathrm{N}$ & $052^{\circ} 16.7^{\prime} \mathrm{W}$ & 054 & 0.3 & 430917 middle of dyke \\
\hline 12 & Ikertooq & $66^{\circ} 50.1^{\prime} \mathrm{N}$ & $052^{\circ} 19.2^{\prime} \mathrm{W}$ & $?$ & $?$ & 430919 middle of dyke \\
\hline 13 & Itilleq & $66^{\circ} 32.25^{\prime} \mathrm{N}$ & $052^{\circ} 45.0^{\prime} \mathrm{W}$ & 080 & 8 & 430923 middle of dyke \\
\hline 14 & Itilleq & $66^{\circ} 32.85^{\prime} \mathrm{N}$ & $052^{\circ} 47.15^{\prime} \mathrm{W}$ & $?$ & 0.1 & 430926 whole width of dyke \\
\hline 15 & Itilleq & $66^{\circ} 33.3^{\prime} \mathrm{N}$ & $052^{\circ} 51.3^{\prime} \mathrm{W}$ & 095 & 1 & 430929 middle of dyke \\
\hline 16 & Itilleq & $66^{\circ} 33.03^{\prime} \mathrm{N}$ & $052^{\circ} 53.54^{\prime} \mathrm{W}$ & 035 & 8 & $\begin{array}{l}430930 \sim 2.5 \text { m from contact, } \\
430931 \text { dyke contact }\end{array}$ \\
\hline 17 & Itilleq & $66^{\circ} 33.5^{\prime} \mathrm{N}$ & $052^{\circ} 56.0^{\prime} \mathrm{W}$ & 080 & 2 & $4309330.3 \mathrm{~m}$ from contact \\
\hline 18 & Itilleq & $66^{\circ} 34.7^{\prime} \mathrm{N}$ & $052^{\circ} 56.0^{\prime} \mathrm{W}$ & 062 & 10 & 430935 middle of dyke \\
\hline 19 & Itilleq & $66^{\circ} 34.7^{\prime} \mathrm{N}$ & $052^{\circ} 56.0^{\prime} \mathrm{W}$ & 090 & 14 & 430936 middle of dyke \\
\hline 20 & Itilleq & $66^{\circ} 35.1^{\prime} \mathrm{N}$ & $052^{\circ} 49.0^{\prime} \mathrm{W}$ & 090 & 8 & 430939 middle of dyke \\
\hline 21 & Itilleq & $66^{\circ} 35.1^{\prime} \mathrm{N}$ & $052^{\circ} 47.5^{\prime} \mathrm{W}$ & 079 & 8 & 430940 middle of dyke \\
\hline 22 & Itilleq & $66^{\circ} 34.75^{\prime} \mathrm{N}$ & $052^{\circ} 48.5^{\prime} \mathrm{W}$ & $?$ & $?$ & 430942 middle of dyke \\
\hline 23 & Itilleq & $66^{\circ} 34.75^{\prime} \mathrm{N}$ & $052^{\circ} 48.5^{\prime} \mathrm{W}$ & $?$ & $?$ & 430943 middle of dyke \\
\hline 24 & Itilleq & $66^{\circ} 33.1^{\prime} \mathrm{N}$ & $053^{\circ} 04.0^{\prime} \mathrm{W}$ & $?$ & 25 & 430946 middle of dyke \\
\hline 25 & Itilleq & $66^{\circ} 33.7^{\prime} \mathrm{N}$ & $052^{\circ} 55.1^{\prime} \mathrm{W}$ & 087 & 16 & $\begin{array}{l}430948 \text { middle of dyke, } \\
430950 \text { dyke contact }\end{array}$ \\
\hline 26 & Itilleq & $66^{\circ} 33.25^{\prime} \mathrm{N}$ & $052^{\circ} 38.5^{\prime} \mathrm{W}$ & 100 & 1 & 430951 middle of dyke \\
\hline 27 & Itilleq & $66^{\circ} 33.25^{\prime} \mathrm{N}$ & $052^{\circ} 33.0^{\prime} \mathrm{W}$ & 096 & 20 & 430952 middle of dyke \\
\hline 28 & Itilleq & $66^{\circ} 32.6^{\prime} \mathrm{N}$ & $052^{\circ} 27.0^{\prime} \mathrm{W}$ & 057 & 30 & 430953 middle of dyke \\
\hline 29 & Itilleq & $66^{\circ} 31.8^{\prime} \mathrm{N}$ & $052^{\circ} 41.0^{\prime} \mathrm{W}$ & 061 & 5 & $\begin{array}{l}430955 \sim 1.5 \mathrm{~m} \text { from contact, } \\
430956 \sim 5 \mathrm{~m} \text { from contact }\end{array}$ \\
\hline 30 & Itilleq & $66^{\circ} 31.9^{\prime} \mathrm{N}$ & $052^{\circ} 38.5^{\prime} \mathrm{W}$ & 085 & 15 & $\begin{array}{l}430957 \text { dyke contact, } \\
430959 \sim 5 \text { m from contact }\end{array}$ \\
\hline 31 & Itilleq & $66^{\circ} 31.8^{\prime} \mathrm{N}$ & $052^{\circ} 36.2^{\prime} \mathrm{W}$ & 065 & 18 & 430960 middle of dyke \\
\hline 32 & Itilleq & $66^{\circ} 31.7^{\prime} \mathrm{N}$ & $052^{\circ} 34.0^{\prime} \mathrm{W}$ & 078 & 22 & 430961 middle of dyke \\
\hline 33 & Mouth of Itilleq & $66^{\circ} 29.9^{\prime} \mathrm{N}$ & $053^{\circ} 33.5^{\prime} \mathrm{W}$ & 022 & 20 & 430965 middle of dyke \\
\hline 34 & Mouth of Itilleq & $66^{\circ} 30^{\prime} \mathrm{N}$ & $053^{\circ} 34.8^{\prime} \mathrm{W}$ & 065 & 25 & $430966 \sim 7 \mathrm{~m}$ from contact \\
\hline 35 & Mouth of Itilleq & $66^{\circ} 30.05^{\prime} \mathrm{N}$ & $053^{\circ} 35.8^{\prime} \mathrm{W}$ & 117 & 40 & $430967 \sim 7 \mathrm{~m}$ from contact \\
\hline 36 & Mouth of Itilleq & $66^{\circ} 30.5^{\prime} \mathrm{N}$ & $053^{\circ} 36.4^{\prime} \mathrm{W}$ & 006 & 10 & 430969 middle of dyke \\
\hline 37 & South of Maniitsoq & $65^{\circ} 22.7^{\prime} \mathrm{N}$ & $052^{\circ} 47.3^{\prime} \mathrm{W}$ & 345 & 4.5 & 430970 middle of dyke \\
\hline 38 & East of Maniitsoq & $65^{\circ} 25.5^{\prime} \mathrm{N}$ & $052^{\circ} 24.0^{\prime} \mathrm{W}$ & ? & 15 & 430972 middle of dyke \\
\hline 39 & East of Maniitsoq & $65^{\circ} 25.4^{\prime} \mathrm{N}$ & $052^{\circ} 23.0^{\prime} \mathrm{W}$ & 054 & 0.4 & 430973 middle of dyke \\
\hline 40 & East of Maniitsoq & $65^{\circ} 25.5^{\prime} \mathrm{N}$ & $052^{\circ} 18.0^{\prime} \mathrm{W}$ & 117 & 12 & 430974 middle of dyke \\
\hline 41 & East of Maniitsoq & $65^{\circ} 26.0^{\prime} \mathrm{N}$ & $052^{\circ} 14.8^{\prime} \mathrm{W}$ & 354 & 7 & 430975 middle of dyke \\
\hline 42 & East of Maniitsoq & $65^{\circ} 35.15^{\prime} \mathrm{N}$ & $052^{\circ} 46.0^{\prime} \mathrm{W}$ & 002 & 49 & $\begin{array}{l}430977 \text { dyke contact, } \\
4309791 \mathrm{~m} \text { from contact, } \\
4309815 \mathrm{~m} \text { from contact, } \\
43098217 \mathrm{~m} \text { from contact }\end{array}$ \\
\hline 43 & N orth of Maniitsoq & $65^{\circ} 39.85^{\prime} \mathrm{N}$ & $052^{\circ} 37.0^{\prime} \mathrm{W}$ & 003 & 25 & $\begin{array}{l}430983 \text { middle of dyke, } \\
430984 \text { dyke contact }\end{array}$ \\
\hline 44 & N orth of Maniitsoq & $65^{\circ} 44.4^{\prime} \mathrm{N}$ & $052^{\circ} 38.5^{\prime} \mathrm{W}$ & 344 & 0.5 & 430986 middle of dyke \\
\hline 45 & N orth of Maniitsoq & $65^{\circ} 38.75^{\prime} \mathrm{N}$ & $052^{\circ} 37.5^{\prime} \mathrm{W}$ & 002 & 16 & $\begin{array}{l}430987 \text { middle of dyke, } \\
430988 \sim 6 \mathrm{~cm} \text { from contact }\end{array}$ \\
\hline 46 & N orth of Maniitsoq & $65^{\circ} 36.9^{\prime} \mathrm{N}$ & $052^{\circ} 43.5^{\prime} \mathrm{W}$ & 005 & 10 & $\begin{array}{l}430990 \sim 4 \mathrm{~m} \text { from contact, } \\
430991 \sim 0.5 \mathrm{~m} \text { from contact }\end{array}$ \\
\hline
\end{tabular}


Table A1 (continued)

\begin{tabular}{|c|c|c|c|c|c|c|}
\hline Dyke & Location & Latitude & Longitude & Trend & Thickness (m) & Samples \\
\hline 47 & N orth of Maniitsoq & $65^{\circ} 40.1^{\prime} \mathrm{N}$ & $052^{\circ} 49.0^{\prime} \mathrm{W}$ & 010 & 17 & 430992 middle of dyke \\
\hline 48 & $\mathrm{~N}$ orth-east of Kangaamiut & $65^{\circ} 54.9^{\prime} \mathrm{N}$ & $053^{\circ} 14.5^{\prime} \mathrm{W}$ & 050 & 12 & $430993 \sim 2 \mathrm{~m}$ from contact \\
\hline 49 & $\mathrm{~N}$ orth-east of K angaamiut & $65^{\circ} 53.95^{\prime} \mathrm{N}$ & $053^{\circ} 16.0^{\prime} \mathrm{W}$ & 045 & 27 & 430994 middle of dyke \\
\hline 50 & $\mathrm{~N}$ orth-east of Kangaamiut & $65^{\circ} 53.4^{\prime} \mathrm{N}$ & $053^{\circ} 14.95^{\prime} \mathrm{W}$ & 033 & 1 & none \\
\hline 51 & $\mathrm{~N}$ orth-east of Kangaamiut & $65^{\circ} 53.4^{\prime} \mathrm{N}$ & $053^{\circ} 14.95^{\prime} \mathrm{W}$ & 110 & 0.2 & none \\
\hline 52 & $\mathrm{~N}$ orth-east of Kangaamiut & $65^{\circ} 53.4^{\prime} \mathrm{N}$ & $053^{\circ} 14.95^{\prime} \mathrm{W}$ & 030 & 1.5 & 430995 middle of dyke \\
\hline 53 & $\mathrm{~N}$ orth-east of Kangaamiut & $65^{\circ} 53.4^{\prime} \mathrm{N}$ & $053^{\circ} 14.95^{\prime} \mathrm{W}$ & 110 & 2 & 430996 middle of dyke \\
\hline 54 & $\mathrm{~N}$ orth-east of Kangaamiut & $65^{\circ} 52.6^{\prime} \mathrm{N}$ & $053^{\circ} 14.0^{\prime} \mathrm{W}$ & 063 & 60 & $\begin{array}{l}430997 \text { andesitic portion of dyke, } \\
430998 \text { mafic portion of dyke }\end{array}$ \\
\hline 55 & N orth-east of Kangaamiut & $65^{\circ} 50.8^{\prime} \mathrm{N}$ & $053^{\circ} 13.0^{\prime} \mathrm{W}$ & 064 & 1.5 & 432101 middle of dyke \\
\hline 56 & $\mathrm{~N}$ orth-east of K angaamiut & $65^{\circ} 50.8^{\prime} \mathrm{N}$ & $053^{\circ} 13.0^{\prime} \mathrm{W}$ & 015 & 15 & 430999 middle of dyke \\
\hline 57 & Søndre Strømfjord & $66^{\circ} 01.4^{\prime} \mathrm{N}$ & $053^{\circ} 28.65^{\prime} \mathrm{W}$ & 028 & 60 & 432103 middle of dyke \\
\hline 58 & Kangerluarsussuaq & $66^{\circ} 17.5^{\prime} \mathrm{N}$ & $053^{\circ} 05.65^{\prime} \mathrm{W}$ & 065 & 40 & $\begin{array}{l}432104 \text { dyke contact, } \\
432105 \text { middle of dyke }\end{array}$ \\
\hline 59 & Kangerluarsussuaq & $66^{\circ} 17.5^{\prime} \mathrm{N}$ & $053^{\circ} 05.8^{\prime} \mathrm{W}$ & 057 & 40 & 432107 middle of dyke \\
\hline 60 & Kangerluarsussuaq & $66^{\circ} 17.25^{\prime} \mathrm{N}$ & $053^{\circ} 07.5^{\prime} \mathrm{W}$ & 022 & 1 & 432108 middle of dyke \\
\hline 61 & Kangerluarsussuaq & $66^{\circ} 17.25^{\prime} \mathrm{N}$ & $053^{\circ} 07.5^{\prime} \mathrm{W}$ & 145 & 45 & $\begin{array}{l}4321061 \text { m from contact, } \\
432108 \text { middle of dyke }\end{array}$ \\
\hline 62 & Kangerluarsussuaq & $66^{\circ} 17.15^{\prime} \mathrm{N}$ & $053^{\circ} 08.5^{\prime} \mathrm{W}$ & 045 & 21 & 432111 middle of dyke \\
\hline 63 & Kangerluarsussuaq & $66^{\circ} 17.05^{\prime} \mathrm{N}$ & $053^{\circ} 11.25^{\prime} \mathrm{W}$ & 028 & 40 & $432112 \sim 7 \mathrm{~m}$ from contact \\
\hline 64 & Kangerluarsussuaq & $66^{\circ} 16.9^{\prime} \mathrm{N}$ & $053^{\circ} 09.7^{\prime} \mathrm{W}$ & 031 & 140 & $\begin{array}{l}432115 \text { dyke contact, } \\
432116 \sim 2.5 \mathrm{~m} \text { from } W \text { contact, } \\
432118 \sim 45 \mathrm{~m} \text { from } W \text { contact, } \\
432119 \sim 70 \mathrm{~m} \text { from W contact, } \\
432120 \sim 95 \mathrm{~m} \text { from W contact, } \\
432121 \sim 19 \mathrm{~m} \text { from } \mathrm{E} \text { contact, } \\
432122 \sim 18 \mathrm{~m} \text { from W contact, } \\
432136 \sim 40 \mathrm{~m} \text { from } W \text { contact, } \\
432137 \text { middle of dyke }\end{array}$ \\
\hline 65 & Kangerluarsussuaq & $66^{\circ} 39.5^{\prime} \mathrm{N}$ & $053^{\circ} 03.0^{\prime} \mathrm{W}$ & 065 & 50 & 432123 middle of dyke \\
\hline 66 & East of Itilleq & $66^{\circ} 29.3^{\prime} \mathrm{N}$ & $052^{\circ} 25.0^{\prime} \mathrm{W}$ & 065 & 15 & 432125 middle of dyke \\
\hline 67 & East of Itilleq & $66^{\circ} 29.1^{\prime} \mathrm{N}$ & $052^{\circ} 24.0^{\prime} \mathrm{W}$ & 050 & 8 & 432128 middle of dyke \\
\hline 68 & East of Itilleq & $66^{\circ} 33.1^{\prime} \mathrm{N}$ & $052^{\circ} 07.5^{\prime} \mathrm{W}$ & 072 & 1 & 432129 middle of dyke \\
\hline 69 & East of Itilleq & $66^{\circ} 31.75^{\prime} \mathrm{N}$ & $052^{\circ} 18.0^{\prime} \mathrm{W}$ & 050 & 4 & 432130 middle of dyke \\
\hline 70 & East of Itilleq & $66^{\circ} 30.5^{\prime} \mathrm{N}$ & $052^{\circ} 27.5^{\prime} \mathrm{W}$ & 090 & 25 & 432138 middle of dyke \\
\hline 71 & East of Itilleq & $66^{\circ} 27.9^{\prime} \mathrm{N}$ & $052^{\circ} 27.0^{\prime} \mathrm{W}$ & 022 & 70 & 432133 middle of dyke \\
\hline 72 & East of Itilleq & $66^{\circ} 26.0^{\prime} \mathrm{N}$ & $052^{\circ} 40.5^{\prime} \mathrm{W}$ & 080 & 5 & 432134 middle of dyke \\
\hline 73 & East of Itilleq & $66^{\circ} 27.45^{\prime} \mathrm{N}$ & $052^{\circ} 45.5^{\prime} \mathrm{W}$ & 055 & 4 & 432135 middle of dyke \\
\hline 74 & Kangerluarsussuaq & $66^{\circ} 16.6^{\prime} \mathrm{N}$ & $053^{\circ} 17.0^{\prime} \mathrm{W}$ & 032 & 17 & 432139 middle of dyke \\
\hline 75 & Kangerluarsussuaq & $66^{\circ} 15.3^{\prime} \mathrm{N}$ & $053^{\circ} 22.5^{\prime} \mathrm{W}$ & 036 & 18 & $\begin{array}{l}432140 \text { middle of dyke, } \\
4321519 \text { m from N contact, } \\
4321526 \text { m from N contact, } \\
4321534 \text { m from N contact, } \\
4321542 \text { m from N contact, } \\
4321551 \text { m from N contact, } \\
4321560.5 \text { m from N contact, } \\
4321570.25 \text { m from N contact, } \\
432158 \text { dyke contact, highly jointed }\end{array}$ \\
\hline 76 & Kangerluarsussuaq & $66^{\circ} 14.6^{\prime} \mathrm{N}$ & $053^{\circ} 33.0^{\prime} \mathrm{W}$ & 020 & 25 & $\begin{array}{l}432143 \text { middle of dyke, } \\
4321445 \text { m from E contact, } \\
432145 \text { E contact }\end{array}$ \\
\hline 77 & Kangerluarsussuaq & $66^{\circ} 14.7^{\prime} \mathrm{N}$ & $053^{\circ} 31.7^{\prime} \mathrm{W}$ & 044 & 0.4 & $\begin{array}{l}432147 \text { N W contact, } \\
432148 \text { middle of dyke } \\
432149 \text { SE contact }\end{array}$ \\
\hline 78 & Kangerluarsussuaq & $66^{\circ} 15.15^{\prime} \mathrm{N}$ & $053^{\circ} 29.0^{\prime} \mathrm{W}$ & 086 & 2 & 432150 middle of dyke \\
\hline 79 & Mouth of Itilleq & $66^{\circ} 30.05^{\prime} \mathrm{N}$ & $053^{\circ} 35.8^{\prime} \mathrm{W}$ & 090 & 50 & 430206 and 430207 middle of dyke \\
\hline 80 & Mouth of Itilleq & $66^{\circ} 30.05^{\prime} \mathrm{N}$ & $053^{\circ} 35.8^{\prime} \mathrm{W}$ & 090 & 15 & 430208 and 430209 middle of dyke \\
\hline 81 & Mouth of Itilleq & $66^{\circ} 30.05^{\prime} \mathrm{N}$ & $053^{\circ} 35.8^{\prime} \mathrm{W}$ & 090 & $?$ & 430210 middle of dyke \\
\hline 82 & Mouth of Itilleq & $66^{\circ} 30.05^{\prime} \mathrm{N}$ & $053^{\circ} 35.8^{\prime} \mathrm{W}$ & 090 & 0.1 & 430211 whole width of dyke \\
\hline 83 & Søndre Strømfjord & $66^{\circ} 01.4^{\prime} \mathrm{N}$ & $053^{\circ} 28.65^{\prime} \mathrm{W}$ & $?$ & $?$ & 430258 dyke contact \\
\hline 84 & $\mathrm{~N}$ orth-east of Kangaamiut & $65^{\circ} 52.6^{\prime} \mathrm{N}$ & $053^{\circ} 14.9^{\prime} \mathrm{W}$ & 022 & 30 & $\begin{array}{l}430267 \text { dyke contact, } \\
430265 \text { middle of dyke }\end{array}$ \\
\hline 85 & $\mathrm{~N}$ orth-east of Kangaamiut & $65^{\circ} 53.6^{\prime} \mathrm{N}$ & $053^{\circ} 14.9^{\prime} \mathrm{W}$ & 045 & 30 & $\begin{array}{l}430283 \text { dyke contact, } \\
430284 \text { middle of dyke }\end{array}$ \\
\hline 86 & N orth-west of Kangaamiut & $65^{\circ} 56.6^{\prime} \mathrm{N}$ & $053^{\circ} 28.0^{\prime} \mathrm{W}$ & 25 & 60 & $\begin{array}{l}158074 \text { and } 430288 \text { dyke contact, } \\
432102 \text { and } 158077 \text { middle of dyke }\end{array}$ \\
\hline
\end{tabular}




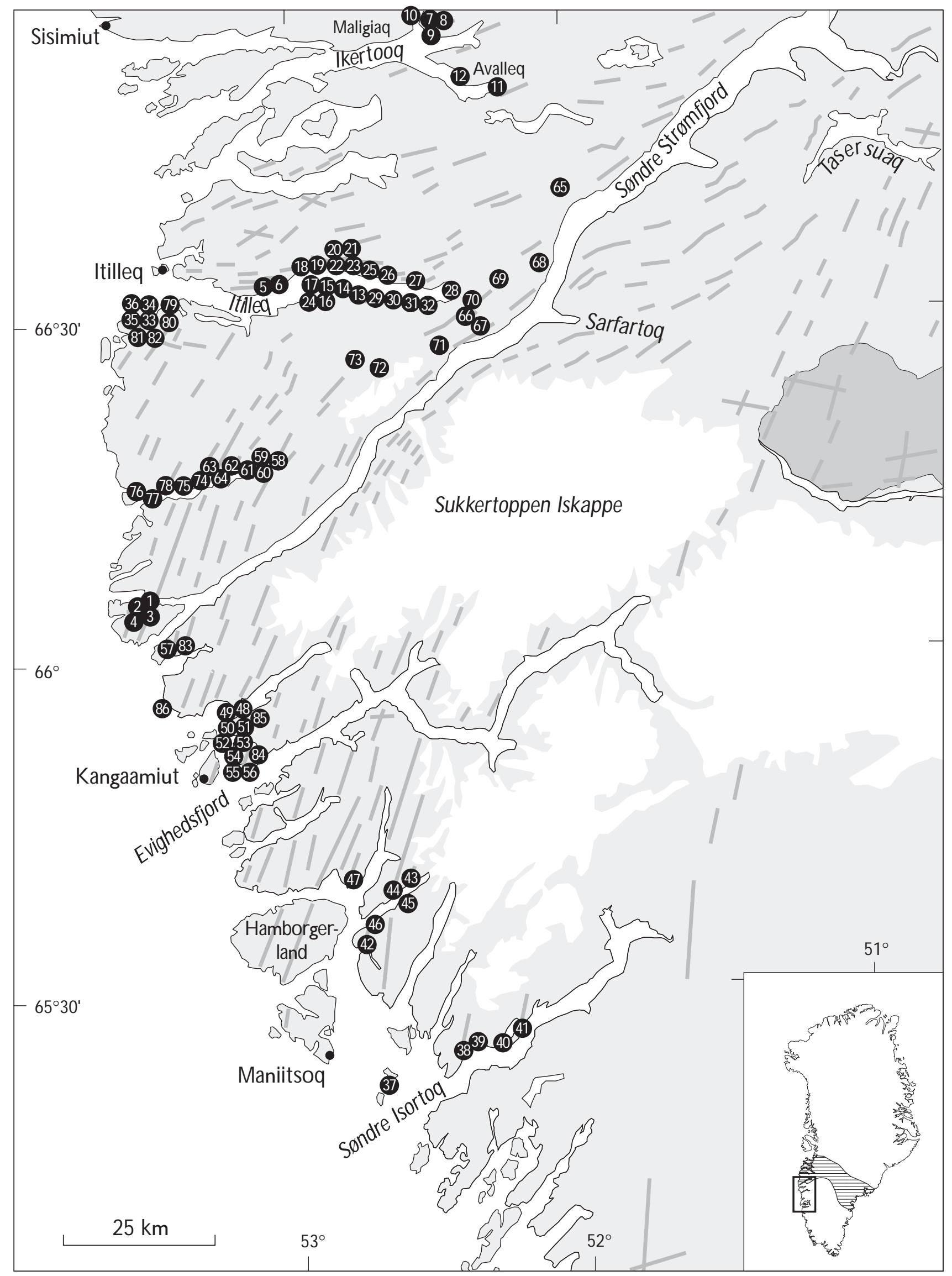

Fig. A1. Map showing the locations of dykes examined in this study. 